

\section{DISCLAIMER}

This report was prepared as an account of work sponsored by an agency of the United States Government. Neither the United States Government nor any agency Thereof, nor any of their employees, makes any warranty, express or implied, or assumes any legal liability or responsibility for the accuracy, completeness, or usefulness of any information, apparatus, product, or process disclosed, or represents that its use would not infringe privately owned rights. Reference herein to any specific commercial product, process, or service by trade name, trademark, manufacturer, or otherwise does not necessarily constitute or imply its endorsement, recommendation, or favoring by the United States Government or any agency thereof. The views and opinions of authors expressed herein do not necessarily state or reflect those of the United States Government or any agency thereof. 


\section{DISCLAIMER}

Portions of this document may be illegible in electronic image products. Images are produced from the best available original document. 


\section{Printed in the United States of America. Available from National Technical Information Service U.S. Department of Commerce 5285 Port Royal Road, Springfield, Virginia 22161 NTIS price codes-Printed Copy: A03 Microfiche A01}

This report was prepared as an account of work sponsored by an agency of the United States Government. Neither the U nited States Government nor any agency thereof, nor any of their employees, makes any warranty, express or implied, or assumes any legal liability or responsibility for the accuracy, completeness, or usefulness of any information, apparatus, product, or process disclosed, or represents that its use would not infringe privately owned rights. Reference herein to any specific commercial product, process, or service by trade name, trademark, manufacturer, or otherwise, does not necessarily constitute or imply its endorsement, recommendation, or favoring by the United States Government or any agency thereof. The views and opinions of authors expressed herein do not necessarily state or reflect those of the United States Government or any agency thereof. 


\section{EFFECTS OF ALTERNATE FUELS REPORT NO. 8: ANALYSIS OF DEGRADATION OF MAGNESIA-BASED REFRACTORY BRICKS FROM A RESIDUAL OIL-FIRED ROTARY CEMENT KILN}

J. I. Federer and V. J. Tennery

Date Published: May 1980

NOTICE This document contains information of a preliminary nature. it is subject to revision or correction and therefore does not represent a final report.

Prepared for Office of Industrial Programs Conservation and Solar Application

Department of Energy

DISCLAIMER

This book was prepared as an aceount of work sponsored by an agency of the United States Government.

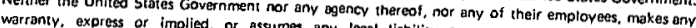
completeness. of usefulness of any informun. represents that its use would not infringe privasely ounnet rights, Reference process disclosed, or commercial product, process. of service by trade name, trademark, manufactwere or to any specitic not neceessarily constituzis of imply its endorsement, recommendatinn. or favoring by inse. does

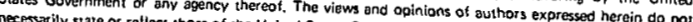
lect those of the United Stotes Government or any agency thereof.

\footnotetext{
OAK RIDGE NATIONAL LABORATORY

Oak Rluye, Telllessee 37030 operated by

UNION CARBIDE CORPORATION for the

DEPARTMENT OF ENERGY
} 


\section{THIS PAGE \\ WAS INTENTIONALLY \\ LEFT BLANK}




\section{CONTENTS}
ABSTRACT

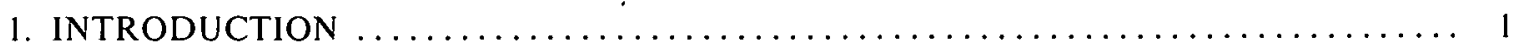

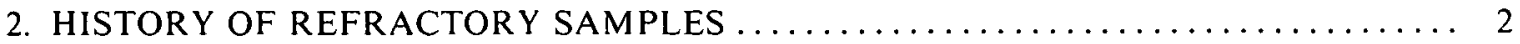
3. PREPARATION OF REFRACTORY SAMPLES FOR ANALYSIS $\ldots \ldots \ldots \ldots \ldots \ldots \ldots .2$

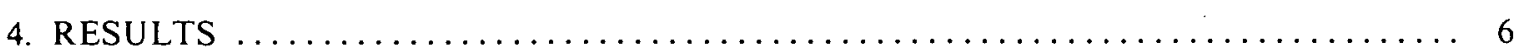

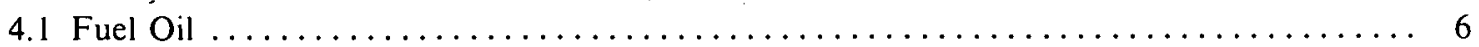

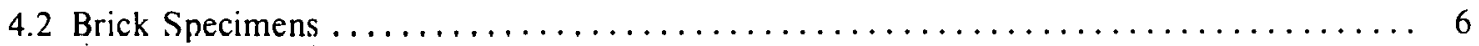

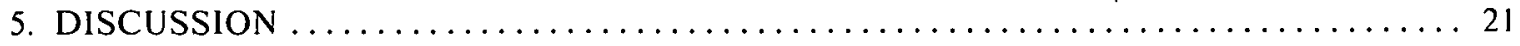

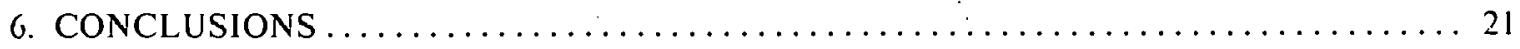

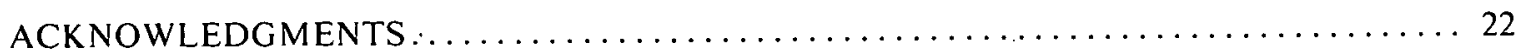

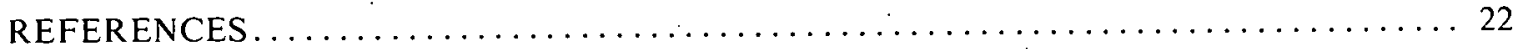




\title{
EFFECTS OF ALTERNATE FUELS REPORT NO. 8: ANALYSIS OF DEGRADATION OF MAGNESIA-BASED REFRACTORY BRICKS FROM A RESIDUAL OIL-FIRED ROTARY CEMENT KILN
}

\begin{abstract}
Residual oil was used as an alternate fuel to natural gas tosupply heat in a rotars cement kiln. Principal impurities in the residual oil were Ca. Fe, Mg. Na, Ni. P.S. and V. The kiln operattors werecencerned about the effects of these oil impurities on observed degradation of the magnesia-batsed bricks used ats a liner in the burning zone of the kiln. Two degraded bricks. which had been in service lor six to nine months. were analyzed to determine the role of fuel impuritics on the obscrved degradation. The miximum hot-face temperature of the ref ractory during service was about $150\left(0^{\circ} \mathrm{C}\right.$. One brick had decreased in thickness about $45 \%$ the other about $15 \%$. Various analytical measurements on these samples latiled to reveal the presence of fuel impurities at or near the hot face of the bricks. and we therefore conclude that the relatively slourt service life of these refractories was not due to use of residual wil ats the lue in the kiln. The obsersed degradation. therefore. was attributed to other reactions and to thermal mechatnical cond itions in the kiln. which incvitably resulted in extensive erosion of the hricks.
\end{abstract}

\section{INTRODUCTION}

Natural gas has been an important industrial fuel for many years. This fuel is clean and is relatively easy to transport and burn compared with other fossil fuels. In recent years, however, shortfalls of natural gas have caused many industries to convert some of their furnaces to distillate oil, residual oil. or coal. Distillate oil is cleaner and easier to transport and burn than residual oil, but residual oil has historically had a lower cost per unit of heat. This economic factor provides an advantage to the use of residual oil unless fuel impurities contaminate the product or substantially contributc to degradation of furnace linings. As a result, residual oil is now burned in many process heat applications in the stecl, glass, cement, and refractory industries and, also, by electric utilities.

There is considerable evidence that the combustion products of residual oil are deleterious to furnace refractories under some conditions. The impurities, which are present in the combustion products as oxides, react with both dense refractories and refractory insulations, resulting in a varicty of effects. The degree of attack depends upon several factors, including the type of refractory, specific fuel impurities, temperature, duration of exposure, oxygen potential, etc. Degradation of refractories by fuels alternate to natural gas, particularly residual oil, has been the subject of recent ORNL investigations. A series of reports describes the effects of coal and residual oil combustion products on various refractories from industrial processes such as a periodic kiln, glass furnace and glass furnace regenerator, steam boiler, soaking-pit cover, and an ind ustrial burner on a lime-type kiln. ${ }^{1-7}$ In addition, a variety of dense refractories and refractory insulations have been exposed to the combustion products of residual oil in the Refractory Test Facility at ORNL. These tests under controlled conditions were conducted for the purpose of elucidating the effects of specific fuel impurities on various refractorics."

This report discusses the analysis of degraded basic bricks that had been used in the lining in the burning zone of an oil-fired cement kiln. The kiln operators needed to know whether impurities in the No. 6 residual oil had been involved in the observed degradation. Our investigation included chemical analysis, $x$-ray diffraction analysis, ceramographic examination, and electron microprobe analysis of the bricks in typical hot- and cold-face regions. 


\section{HISTORY OF REFRACTORY SAMPLES}

The original refractories, illustrated in Fig. 1, were standard-size magnesia-based tapered bricks designed to be used as a lining for a cement kiln or other vessel of circular cross section. The steel shim plate on one side of the brick serves the dual purpose of tightening and bonding a ring of bricks in place in the lining. During installation, extra steel shims are driven between the bricks as required to assure a tight-fitting shell ring. The steel oxidizes during service and reacts with $\mathrm{MgO}$ in the brick to form a bonding phase consisting of $\mathrm{MgO} \cdot \mathrm{Fe}_{2} \mathrm{O}_{3}$.

Two types of bricks (both magnesia-based, but different compositions) were installed in a checkerboard pattern in the hot zone or clinkering zone of a rotary cement kiln. The kiln was heated by burning No. 6 residual oil (as an alternate to natural gas) at one end of the kiln, as shown in Fig. 1. The wet feed material, typically consisting of limestone; shale or clay, iron ore, and sand, enters the kiln at the cool end and exits at the hot end. These materials are first dried, then heated, and finally calcined during passage through the kiln. In the burning zorle, where a temperature of about $\left.1500^{\circ} \mathrm{C}(\sim 270)^{n} r\right)$ occurs, the feed materials are changed into new compounds, such as dicalcium and tricalcium silicate, tricalcium aluminate, and tetracalcium aluminoferrite. Liquid phases are present during these reactions. The product emerges from the kiln as round, marble-size balls called cement clinker. Aluminosilicate relractories cannot be used in the kiln hot zone because reactions with calcia form undesirable low-melting eutectics when the operating temperature exceeds about $1300^{\circ} \mathrm{C}\left(2370^{\circ} \mathrm{F}\right)$.

This clinker also forms a coating on the hot lace of the brick. The coating occasionally spalls away, then re-forms. Spalling usually removes a thin layer of brick each time it occurs. General kiln practice requires that the brick lining be replaced when the spalling process reduces the thickness of the brick to about $7.5 \mathrm{~cm}$ because the reduced insulation capability of the thinner refractory causes the outer steel shell to overheat.

The composition of the magnesia-based brick is designed to producc a smooth transition in composition between the brick and the clinker coating, thereby minimizing stresses caused by differences in thermal expansion. Nevertheless, the lifetime of the brick lining is strongly influenced by thermal stresses during temperature lluctuations, particularly those associated with kiln shutdowns.

Thus, magnesiat-based brick are used in the hot zone of a rotary cement kiln where the hot-lace temperature reaches $\sim 1500^{\circ} \mathrm{C}$. The hot face of the brick in this case wals coated with clinker which periodically spalled away, removing a thin layer of brick each time, as mentioned carlier. In addition, the brick was exposed to impurities in the No. 6 fuel oil used to fire the kiln. Sections of two bricks were obtained for analysis. During the six to nine months that the bricks were exposed to the above service conditions, the hot lace receded until the radial dimension of the brick decreased to about $8.3 \mathrm{~cm}\left(3^{1}+\mathrm{in}\right.$.) in the case of one brick and to about $12.7 \mathrm{~cm}(5 \mathrm{in}$.) in the other. The different amounts of erosioncorrosion experienced by the two brick specimens could be duc to dilferent initial compositions. different locations in the kiln. or to other factors.

\section{PREPARATION OF REFRACTORY SAMPLES FOR ANALYSIS}

The sections of two bricks received for analysis are shown in Figs. 2 and 3. The hot face on each brick was irregularly shaped rather than flat, as in the case of the original brick shown in Fig. I. A lightgreen adherent coating was present on the hot face of each brick. Figures 4 and 5 show how the bricks were sectioned with a diamond abrasive wheel to obtain samples for analyses. The disposition of these samples is shown in Table 1.

Samples for chemical analysis required about $30 \mathrm{~g}$ of material. In the case of hot-facc samples wc cut approximately parallel to the hot face to obtain $\sim 6$-mm-thick specimens, which would be most 


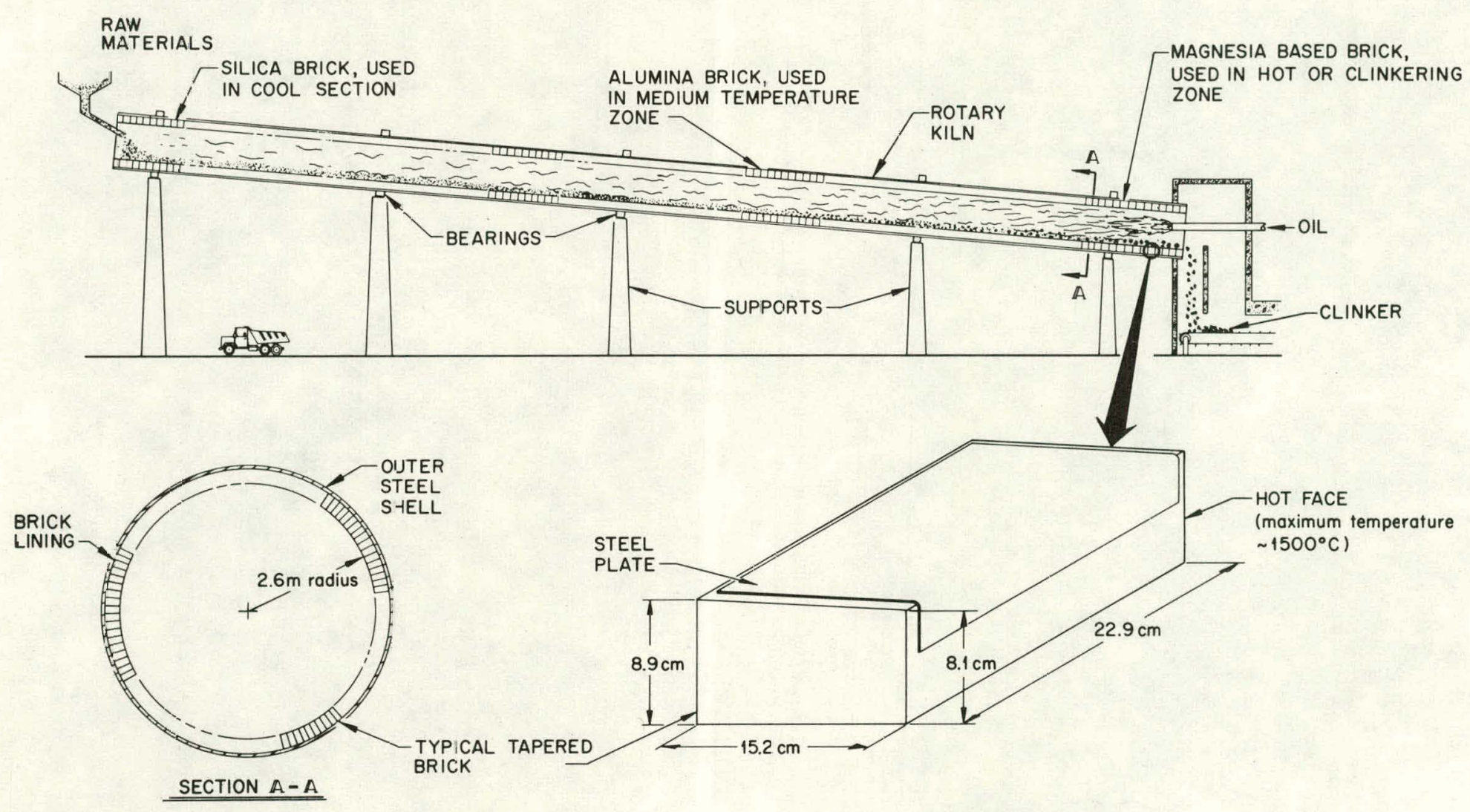

Fig. 1. Schematic of rotary cement kiln and magnesia-based brick. 


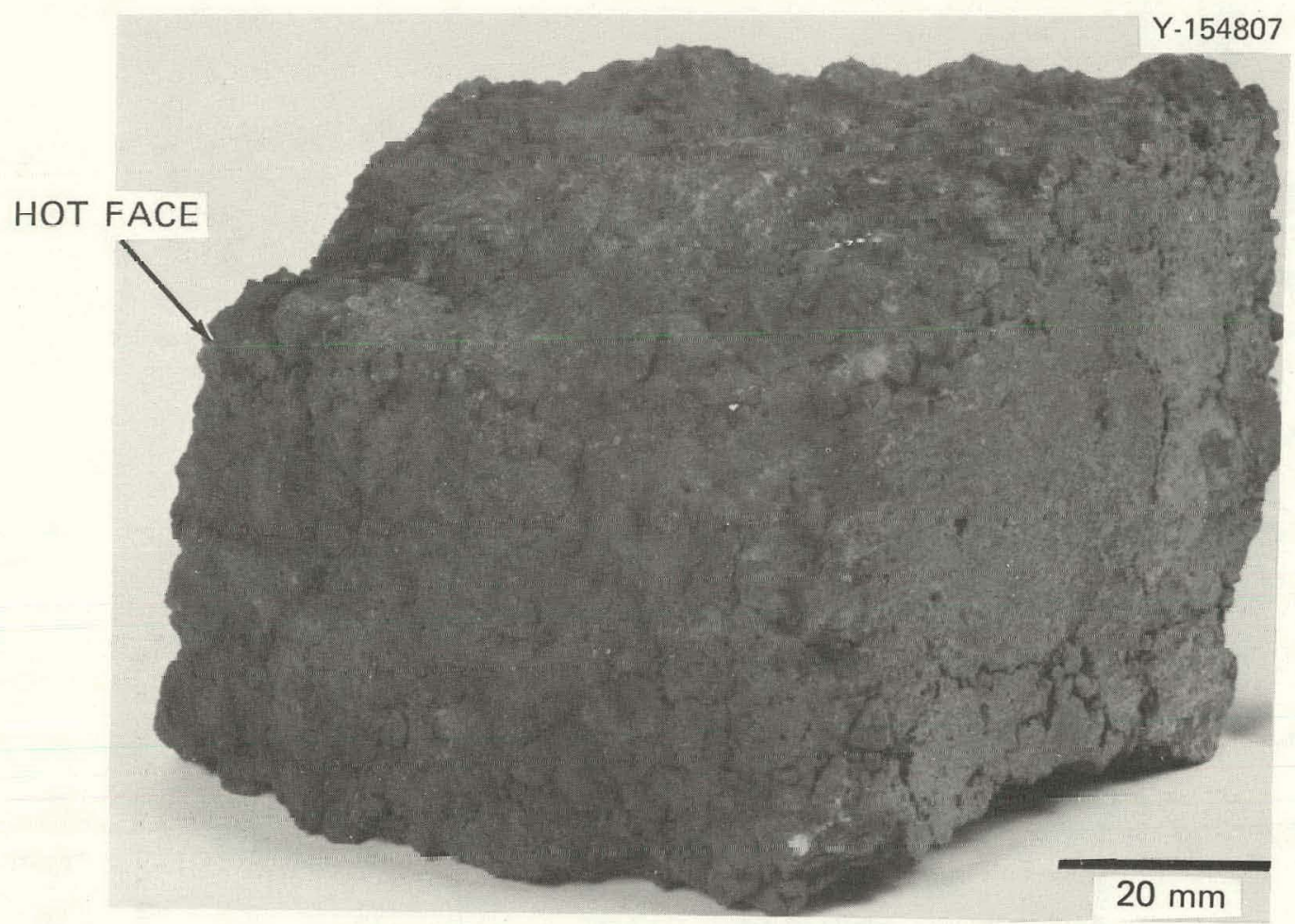

Fig. 2. Degraded small-brick specimen. Note the rough appearance of the hot face.

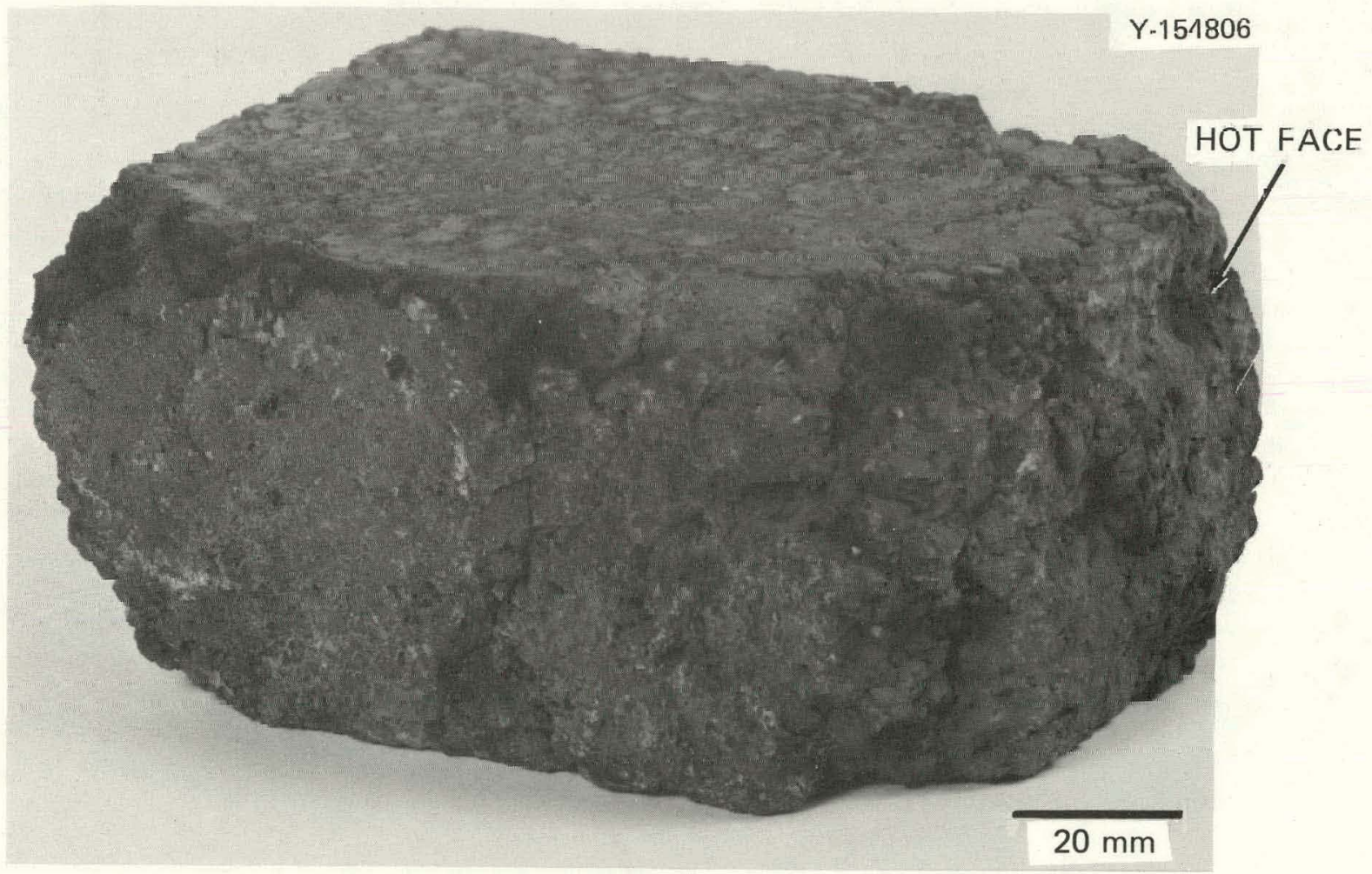

Fig. 3. Degraded large-brick specimen. Note the rough appearance of the hot face. 
ORNL-DWG $78-21777$

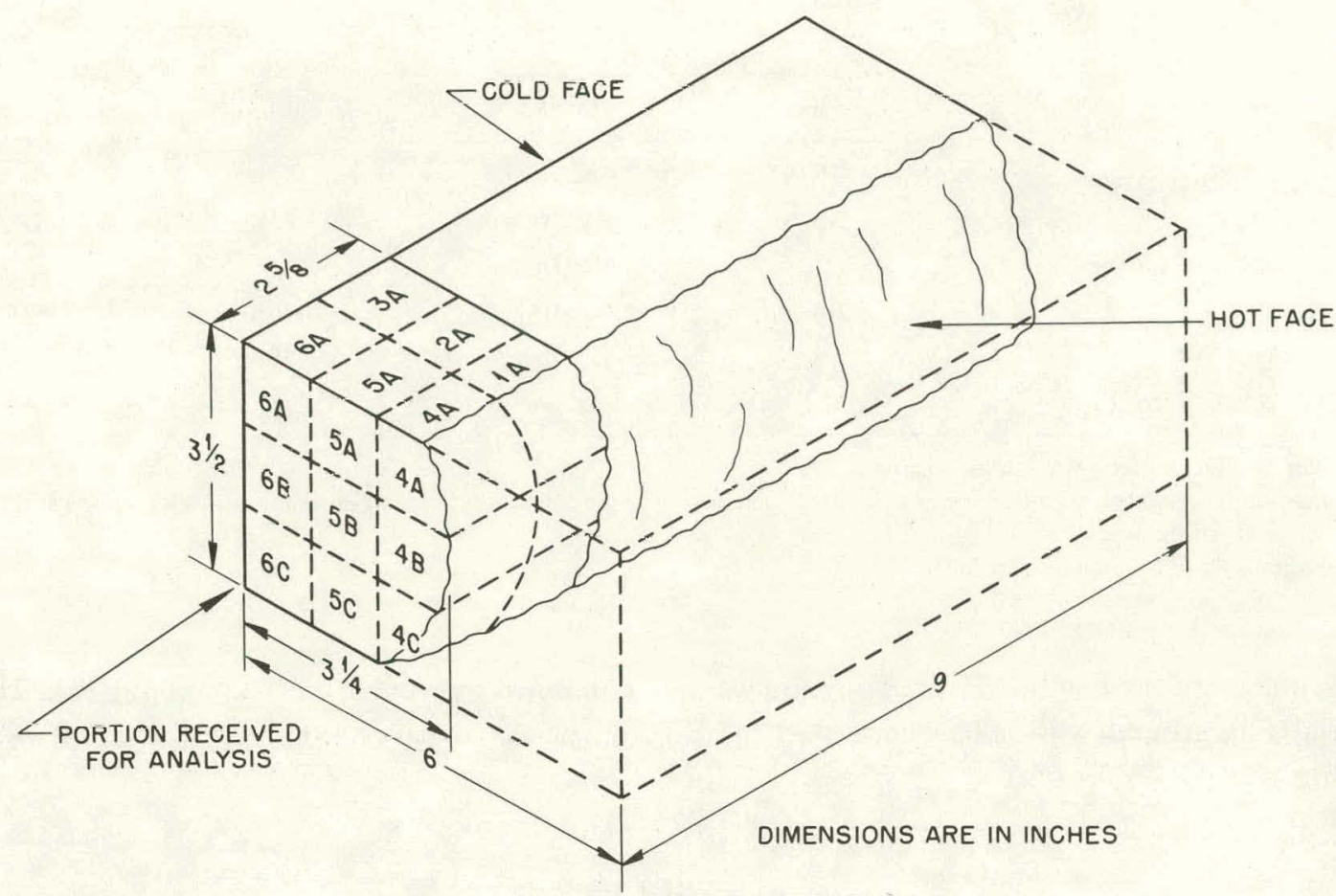

Fig. 4. Relationship of small-brick specimen to original brick, and the sampling plan.

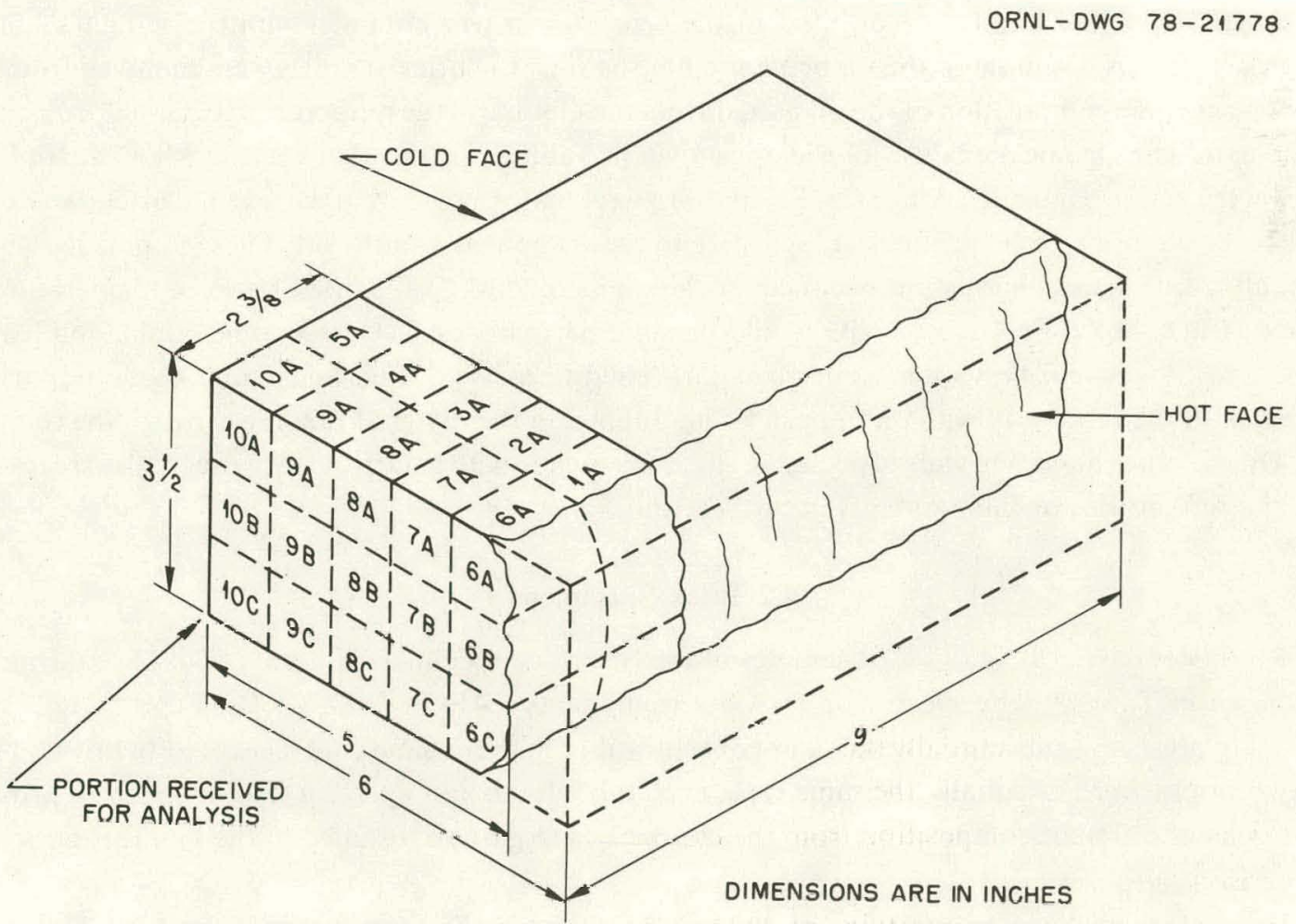

Fig. 5. Relationship of large-brick specimen to original brick, and the sampling plan. 
Table 1. Samples of bricks for various analyses

\begin{tabular}{|c|c|c|c|c|}
\hline & \multicolumn{4}{|c|}{ Sample code ${ }^{a}$} \\
\hline & \multicolumn{2}{|c|}{ Small brick } & \multicolumn{2}{|c|}{ Large brick } \\
\hline & Cold face & Hot face & Cold face & Hot face \\
\hline Chemical analysis & $3 \mathrm{~B}$ & $4 \mathrm{~A}, 4 \mathrm{C}, 1 \mathrm{~B}^{a}$ & $5 B$ & IB. $1 C^{b}$ \\
\hline X-ray diffraction & $3 \mathrm{~B}$ & $4 \mathrm{~A}, 4 \mathrm{C}, 1 \mathrm{~B}^{b}$ & $5 B$ & $1 \mathrm{~B}, 1 \mathrm{C}^{b}$ \\
\hline X-ray diffraction of surface layer & & $1 \mathrm{~A}^{c}$ & & $6 C^{c}$ \\
\hline Ceramography & $6 \mathrm{~B}$ & $4 \mathrm{~B}$ & $10 \mathrm{~B}$ & $6 \mathrm{~B}$ \\
\hline Electron microprobe & $3 \mathrm{~B}$ & $4 \mathrm{~B}$ & $10 \mathrm{~B}$ & $6 \mathrm{~B}$ \\
\hline Scanning electron microscopy & & $1 \mathrm{~A}$ & & $6 \mathrm{~A}$ \\
\hline
\end{tabular}

${ }^{a}$ Refer to rigs. 4 and 5 tor sample locations.

${ }^{b}$ These samples were sectioned further by cutting approxinutely parallel to hot face to obtain 6-mm-thick samples, which were combined for analyses.

'Scrapings from the reaction surface.

representative of the reaction layer. The samples were combined to provide a mass of about $30 \mathrm{~g}$. This material was ground with a hardened-steel mortar and pestle to pass a 100 -mesh screen $(150)-\mu \mathrm{m}$ openings).

\section{RESULTS}

\subsection{Fuel Oil}

A sample of the No. 6 fuel oil used in the cement kiln was obtained with the refractory brick samples. This was a sample of the oil being used at the time the brick samples were removed from the kiln. The average composition of the oil used during the lifetime of the refractories was not documented by the user. The chemical analysis of the oil, shown in Table 2, reveals that $\mathrm{Ca}$. Fe, Mg, Na, Ni, P, S, and $\mathrm{V}$ were major impurities. Since $\mathrm{Ca}, \mathrm{Fe}$, and $\mathrm{Mg}$ were major elements in the original brick, we wuuld not expect the brick to be particularly sensitive to these impurities in the oil. These impurities would probably exist in the combustion products of the vil as oxides. At the brick hot-face temperature of $1500^{\circ} \mathrm{C}, \mathrm{CaO}, \mathrm{MgO}, \mathrm{Fe}_{3} \mathrm{O}_{4}$. and $\mathrm{NiO}$ would be solid particulates; $\mathrm{V}_{2} \mathrm{O}_{5}$ would he liquid; and $\mathrm{Na}_{2} \mathrm{O}_{2}$, $\mathrm{P}_{2} \mathrm{O}_{i}$, and $\mathrm{SO}_{2}$ would be vapors under standard conditions. The solid and liquid oxide impurities may stick to the refractory wall on impact, or be trapped in the material flowing through the rotating kiln. On the other hand, the vapor species might easily escape with little residenec time unless reactions with the refractories or kiln contents occur very quickly.

\subsection{Brick Specimens}

Results of chemical analyses of samples of the two brick specimens in terms of oxide equivalents are shown in Table 3. The six principal oxide components- $\mathrm{Al}_{2} \mathrm{O}_{3}, \mathrm{CaO}, \mathrm{Cr}_{2} \mathrm{O}_{3}, \mathrm{Fe}_{2} \mathrm{O}_{3}, \mathrm{MgO}$, and $\mathrm{SiO}_{2}$ - are present in substantially the same concentrations in the hot and cold faces of both bricks. Thus the two bricks were essentially the same type, even though the kiln operator had intended to provide two bricks of different composition from the checkerboard pattern installed in the kiln for refractory comparison purposes.

In some cases the concentrations of $\mathrm{Al}_{2} \mathrm{O}_{3}, \mathrm{Cr}_{2} \mathrm{O}_{3}$, and $\mathrm{Fe}_{2} \mathrm{O}_{3}$ are not within the typical range of values specified by the manufacturer of the brick. The concentration of $\mathrm{Cr}_{2} \mathrm{O}_{3}$ in the hot face of each 
Table 2. Chemical analysis of No. 6 residual fuel oil

Sample obtained with cement kiln refractory samples

\begin{tabular}{lc}
\hline Element & $\begin{array}{c}\text { Concentration } \\
(\mathrm{ppm})\end{array}$ \\
\hline $\mathrm{Al}$ & 1.4 \\
$\mathrm{Ba}$ & 0.6 \\
$\mathrm{Ca}$ & 26 \\
$\mathrm{Cr}$ & 1 \\
$\mathrm{Cu}$ & 7.5 \\
$\mathrm{Fe}$ & 47 \\
$\mathrm{~K}$ & 0.1 \\
$\mathrm{Mg}$ & 14 \\
$\mathrm{Na}$ & 18 \\
$\mathrm{Ni}$ & 71 \\
$\mathrm{P}$ & 24 \\
$\mathrm{~Pb}$ & 1.2 \\
$\mathrm{~S}$ & $1.34 \%$ \\
$\mathrm{Si}$ & 0.4 \\
$\mathrm{Ti}$ & 4.0 \\
$\mathrm{~V}$ & 50 \\
$\mathrm{Zn}$ & 3.3 \\
\hline
\end{tabular}

Table 3. Chemical analyses of samples from cold and hot faces of magnesia-based bricks ${ }^{a}$

\begin{tabular}{|c|c|c|c|c|c|}
\hline & \multicolumn{4}{|c|}{ Concentration $(\%)$} & \multirow[b]{3}{*}{ Typical range } \\
\hline & \multicolumn{2}{|c|}{ Small brick } & \multicolumn{2}{|c|}{ Large brick } & \\
\hline & $\begin{array}{l}\text { Cold face, } \\
\text { sample 3B }\end{array}$ & $\begin{array}{c}\text { Hot face, } \\
\text { samples } 4 \mathrm{~A}, 4 \mathrm{C}, 1 \mathrm{~B}\end{array}$ & $\begin{array}{l}\text { Cold face, } \\
\text { sample } 5 B\end{array}$ & $\begin{array}{c}\text { Hot face, } \\
\text { samples 1B, IC }\end{array}$ & \\
\hline $\mathrm{Ag}_{2} \mathrm{O}$ & 0.001 & 0.001 & 0.001 & 0.001 & \\
\hline $\mathrm{Al}_{2} \mathrm{O}_{3}$ & 3.41 & 3.79 & 4.10 & 3.49 & 2.93 .7 \\
\hline $\mathrm{B}_{2} \mathrm{O}_{3}$ & 0.003 & 0.003 & 0.003 & 0.003 & \\
\hline $\mathrm{CaO}$ & 19.29 & 19.18 & 19.56 & 19.04 & $19.0 \quad 21.0$ \\
\hline $\mathrm{CoO}$ & 0.001 & 0.001 & 0.001 & 0.001 & \\
\hline $\mathrm{Cr}_{2} \mathrm{O}_{3}$ & 3.53 & 2.54 & 3.03 & 2.52 & 3.34 .9 \\
\hline $\mathrm{CuO}$ & 0.005 & 0.003 & 0.003 & 0003 & \\
\hline $\mathrm{Fe}_{2} \mathrm{O}_{3}$ & 5.61 & 5.39 & 5.36 & 5.29 & 5.87 .0 \\
\hline $\mathrm{K}_{2} \mathrm{O}$ & 0.08 & 0.90 & 0.06 & 0.28 & \\
\hline L.O. $\mathrm{I}^{b}$ & 2.10 & 1.49 & 0.31 & 0.56 & \\
\hline $\mathrm{MgO}$ & 54.68 & 55.08 & 55.92 & 57.30 & 53.757 .7 \\
\hline $\mathrm{MnO}$ & 0.005 & 0.005 & 0.005 & 0.005 & \\
\hline $\mathrm{MoO}_{3}$ & 0.001 & 0.001 & 0.001 & 0.001 & \\
\hline $\mathrm{Na}_{2} \mathrm{O}$ & 0.13 & 0.19 & 0.14 & 0.17 & \\
\hline $\mathrm{NiO}$ & 0.005 & 001 & 0.008 & 0.008 & \\
\hline $\mathrm{P}_{2} \mathrm{O}_{5}$ & $<0.10^{c}$ & $<0.10^{c}$ & $<0.10^{c}$ & $<0.10^{\circ}$ & \\
\hline $\mathrm{PbO}$ & 0.001 & 0.001 & 0.001 & 0.001 & \\
\hline $\mathrm{SO}_{2}$ & 0.035 & 0.11 & 0.025 & 0.15 & \\
\hline $\mathrm{SiO}_{2}$ & 10.94 & 11.20 & 11.20 & 11.04 & 9.711 .3 \\
\hline $\mathrm{SrO}$ & 0.005 & 0.008 & 0.005 & 0.05 & \\
\hline $\mathrm{TiO}_{2}$ & 0.12 & 0.08 & 0.13 & 0.10 & \\
\hline $\mathrm{V}_{2} \mathrm{O}_{5}$ & 0.001 & 0.001 & U.U0I & 0.002 & \\
\hline
\end{tabular}

${ }^{a}$ Not detected: As, Ba, Be, Bi, Cd, Ge, Sb, Sn, Te, W, Zn, and Zr.

${ }^{b}$ Loss on ignition.

${ }^{c}$ Not detected. The number indicates the minimum limit of detection. 
brick is below that in the cold face, as well as being out of the specified compositional rangc. The analytical data alone are insufficient to determine whether these disagreements are due to degradation reactions, original compositional nonhomogeneity in the bricks, or some other cause.

The concentrations of only three major oil impurities ( $\mathrm{Mg}, \mathrm{Na}$, and S) were higher in the hot face of both bricks than in the cold face; however, we do not believe that the increased magnesium content was derived from the fuel oil. Instead, we suspect that the data in Table 3 show normal compositional variations in magnesium, which coincidentally indicate an increase of magnesium in the hot face. The higher sodium content might have been derived from the fuel oil, or might have come from the product being heated in the kiln. The higher potassium content, a minor oil impurity, also might have come from the kiln product, since the shale or clay raw material no doubt contained alkalies. The increased sulfur content was probably derived from the fuel oil.

$\mathrm{X}$-ray diffraction patterns of powdered samples were prepared using $\mathrm{Cu} K \alpha$ radiation. Using these patterns we determined the phases present in three regions: (1) the culd face, (2) the hot face, which included material to a depth of $\sim 6 \mathrm{~mm}$ from the hof fare; and (3) scrupings from the livl lace. The patterns from each region were very similar; therefore, we concluded that the same phases, shown in Table 4 , were present in the hot- and cold-face regions. The data showed that periclase $(\mathrm{MgO})$ was definitely present. The next five phases-magnesiochromite $\left[(\mathrm{Mg}, \mathrm{Fe})(\mathrm{Cr}, \Lambda \mathrm{ll})_{2} \mathrm{O}_{4}\right]$, magnesium iron aluminum oxide $\left(\mathrm{MgFeAlO}_{4}\right)$, chlorospinel $\left(\mathrm{Mg}_{6.8} \mathrm{Fe}_{0.8} \mathrm{Al}_{11} \mathrm{O}_{32}\right)$, magnesium aluminum chromium oxide $\left(\mathrm{MgAlCrO}_{4}\right)$, and iron chromite $\left[\mathrm{Fe}(\mathrm{Al}, \mathrm{Cr})_{2} \mathrm{O}_{4}\right]$ - have similar interplanar spacings, and distinguishing among them is difficult on the basis of $\mathrm{x}$-ray diffraction alone. Any or all five of these phases could be present in the samples. The presence of magnesiochromite is supported by electron microprobe data to be presented later. The other phases indicated to be present include spinel $\left(\mathrm{MgO} \cdot \mathrm{Al}_{2} \mathrm{O}_{3}\right)$, magnesioferrite $\left(\mathrm{MgO} \cdot \mathrm{Fe}_{2} \mathrm{O}_{3}\right)$, calcium magnesium aluminum ferrite $\left.\left(\mathrm{Ca}_{2} \mathrm{MgAlFeO}\right)_{6}\right)$, diopside $\left(\mathrm{CaO} \cdot \mathrm{MgO} \cdot 2 \mathrm{SiO}_{2}\right)$, monticellite $\left(\mathrm{CaO} \cdot \mathrm{MgO} \cdot \mathrm{SiO}_{2}\right)$, calcium orthosilicate $\left(2 \mathrm{CaO} \cdot \mathrm{SiO}_{2}\right)$, and anorthite $\left.\left(\mathrm{CaO} \cdot \mathrm{Al}_{2} \mathrm{O}_{2} \cdot 2 \mathrm{SiO}\right)\right)$ We fnund no phases in the hot facc invulving the five major oll impurities which were not already major elements in the brick, that is, Na, Ni, P, S, and V. Of course, a phase amounting to less than about $5 \mathrm{vol} \%$ of the total sample probably would not be clearly identifiable by $\mathrm{x}$-ray diffraction techniques; therefore, we employed electron microprobe analysis to search for impurities not revealed by bulk chemical analyses or by $\mathrm{x}$ ray diffraction.

The microstructure of the large brick in an area of the cold face is shown in Fig. 6. Figure $6 a$ shows that the material consists of large dense particles of magnesiochromite in a matrix of smaller particles.

Table 4. Results of x-ray diffraction analysis of magnesia-based bricks

\begin{tabular}{ll}
\hline \multicolumn{1}{c}{ Phases } & Identification status \\
\hline Periclase, $\mathrm{MgO}$ & Present \\
Magnesiochromite, $(\mathrm{Mg}, \mathrm{Fe})(\mathrm{Cr}, \mathrm{Al})_{2} \mathrm{O}_{4}$ & Present \\
Magnesium iron aluminum oxide, $\mathrm{MgFeAlO}_{4}$ & Possible \\
Chlorospinel, $\mathrm{Mg}_{6.8} \mathrm{Fe}_{0.8} \mathrm{Al}_{11} \mathrm{O}_{32}$. & Possible \\
Magnesium aluminum chromium oxide, $\mathrm{MgAlCrO}_{4}$ & Possible \\
Aluminum chromite, $\mathrm{Fe}(\mathrm{Al}, \mathrm{Cr})_{2} \mathrm{O}_{4}$ & Possible \\
Spinel, $\mathrm{MgO} \cdot \mathrm{Al}_{2} \mathrm{O}_{3}$ & Possible \\
Magnesioferrite, $\mathrm{MgO} \cdot \mathrm{Fe}_{2} \mathrm{O}_{3}$ & Possible \\
Calcium magnesium aluminum ferrite, $\mathrm{Ca}_{2} \mathrm{MgAlFeO}_{6}$ & Possible \\
Diopside, $\mathrm{CaO} \cdot \mathrm{MgO} \cdot 2 \mathrm{SiO}_{2}$ & Present \\
Monticellite, $\mathrm{CaO} \cdot \mathrm{MgO} \cdot \mathrm{SiO}_{2}$ & Present \\
Calcium orthosilicate, $2 \mathrm{CaO} \cdot \mathrm{SiO}_{2}$ & Possible \\
Anorthite, $\mathrm{CaO} \cdot \mathrm{Al}_{2} \mathrm{O}_{3} \cdot 2 \mathrm{SiO}_{2}$ & Possible \\
\hline
\end{tabular}




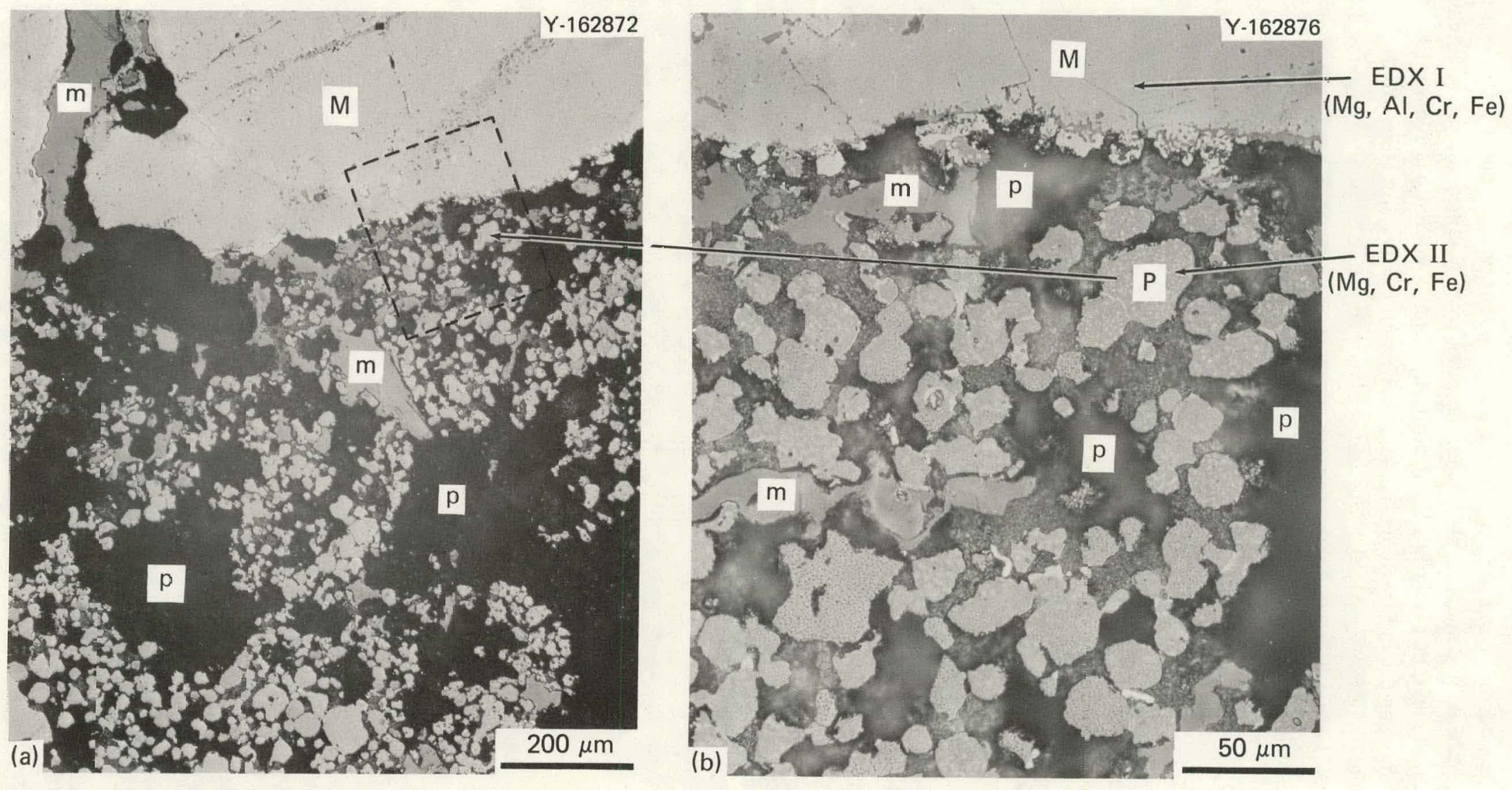

Fig. 6. Microstructure of cold face of large brick (sample 10B). (a) Showing porcsity in the matrix of small grains, 100X. (b) Showing that small grains are loosely .oined, $400 \times . M$ : magnesiochromite, $(\mathrm{Mg}, \mathrm{Fe})\left(\mathrm{Cr}, \mathrm{Al}_{2} \mathrm{O}_{4} ; P\right.$ : periclase, $\mathrm{MgO} ; m$ : mounting material; $p$ : porosity. 
Much porosity is evident among the smaller particles (Fig. $6 a$ ), which appear to be loosely joined together (Fig. 6b). Energy-dispersive X-ray analysis plots were obtained for the microconstituents shown in Fig. 6, wherein EDX I and EDX II indicate typical areas analyzed. The plot for EDX I in Fig. 7 shows that the large particle in Fig. 6 contains $\mathrm{Mg}, \mathrm{Al}, \mathrm{Cr}$, and Fe; therefore, the particle most likely is magnesiochromite $\left[(\mathrm{Mg}, \mathrm{Fe})(\mathrm{Cr}, \mathrm{Al})_{2} \mathrm{O}_{4}\right]$, one of the phases shown to be present by $\mathrm{x}$-ray diffraction. The plot for EDX II in Fig. 8 shows that the smaller, loosely joined particles in Fig. 6 contain magnesium as the major element, with smaller amounts of $\mathrm{Cr}, \mathrm{Mn}$, and $\mathrm{Fe}$. The particles probably consist of periclase $(\mathrm{MgO})$, with $\mathrm{Cr}, \mathrm{Mn}$, and $\mathrm{Fe}$ in solid solution, and magnesioferrite $\left(\mathrm{MgO} \cdot \mathrm{Fe}_{2} \mathrm{O}_{3}\right)$. Essentially the same results were obtained for any of the small particles shown in Fig. 6, even though they differ in appearance, some containing small uniformly dispersed white areas and others having small uniformly dispersed black areas.

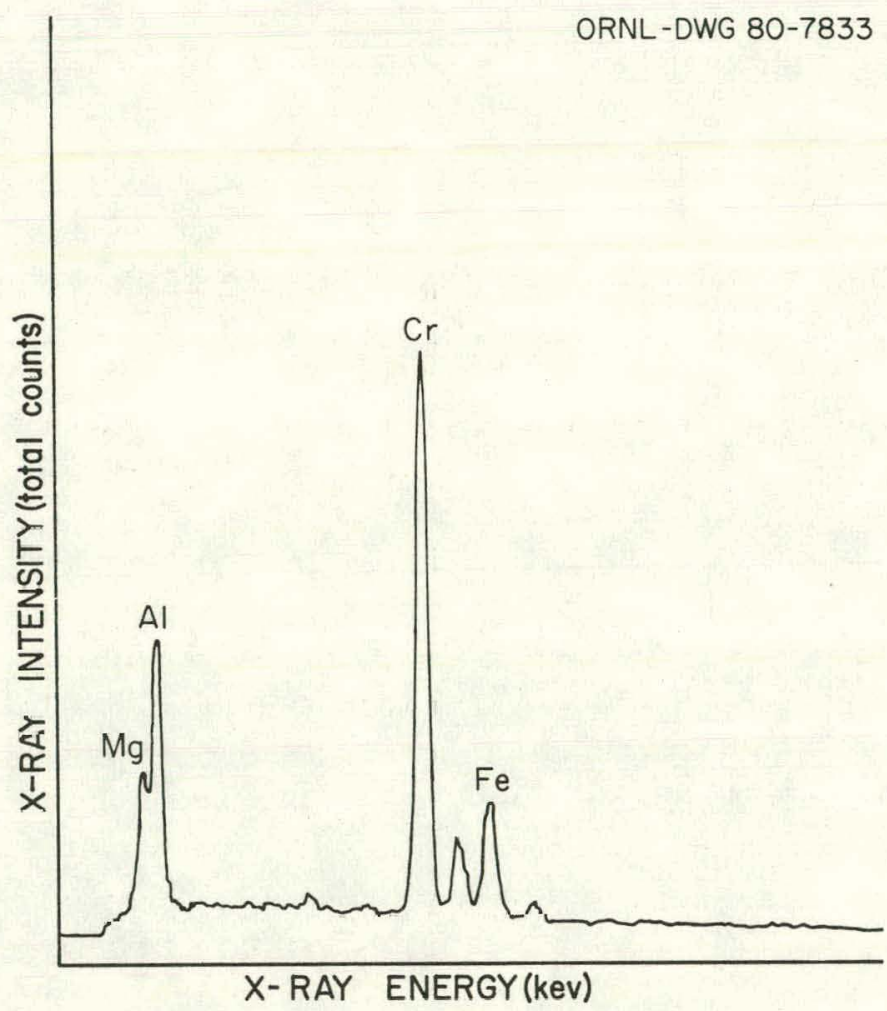

Fig. 7. Energy-dispersive x-ray analysis plot for large brick: large particle in Fig. 6 (EDX I).

The microstructure at the hot face shown in Fig. 9 was similar in appearance to that at the cold face, except for a region of apparently more densely packed grains. Denser regions, such as that shown in Fig. 9, were found only at isolated sites along the hot-face surface. We suspected that these regions would reveal information about degradation reactions. Energy-dispersive x-ray analysis plots for the areas indicated in Fig. 9 (EDX III and EDX IV) are shown in Figs. 10 and 11. Figure 10 shows that the light-gray area (EDX III) in the region of dense grains in Fig. 9 consisted mainly of magnesium with a small amount of iron; therefore, these areas are periclase, with iron in solid solution. Figure 11 shows that the medium-gray areas (EDX IV) in Fig. 9 contain $\mathrm{Mg}$, Si, and $\mathrm{Ca}$. These areas probably consist 


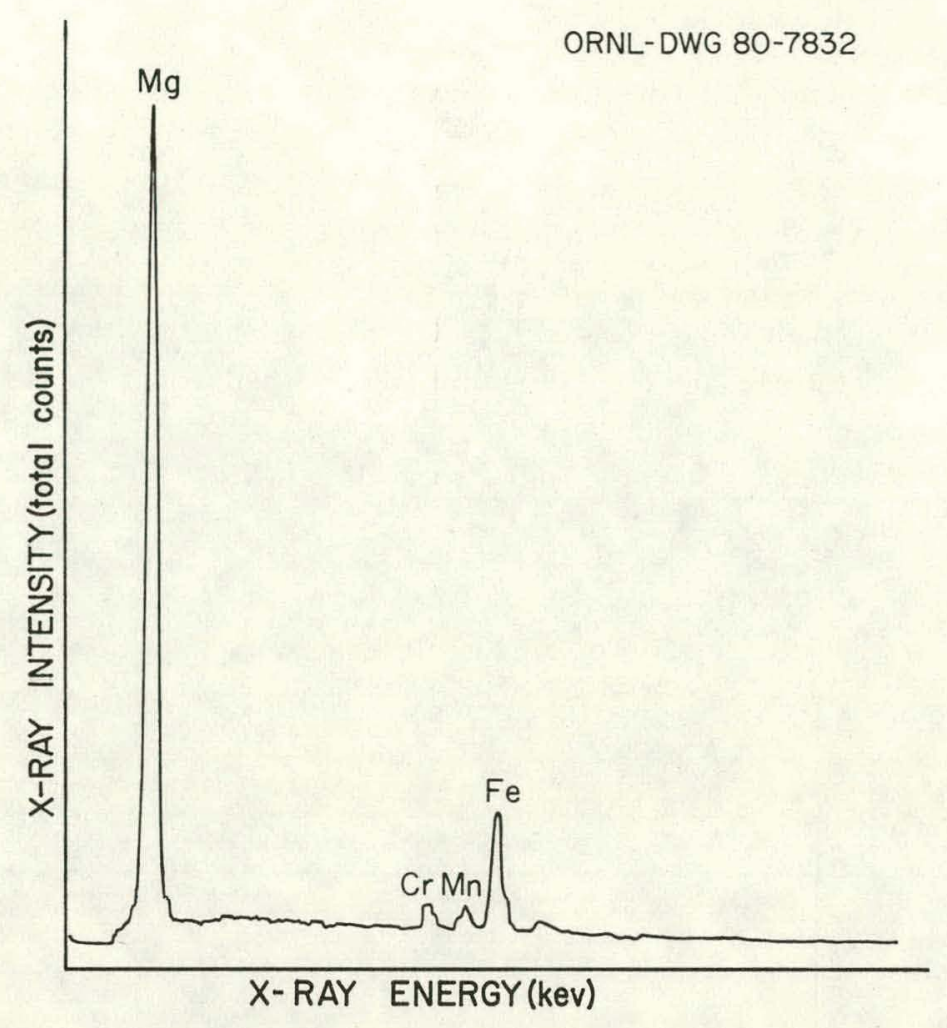

Fig. 8. Energy-dispersive x-ray analysis plot for large brick: small particles in Fig. 6 (EDX II).

of diopside $\left(\mathrm{CaO} \cdot \mathrm{MgO} \cdot 2 \mathrm{SiO}_{2}\right)$ and/ or monticellite $\left(\mathrm{CaO} \cdot \mathrm{MgO} \cdot \mathrm{SiO}_{2}\right)$. Another typical section through the hot-face surface is shown in Fig. 12. The microstructure is similar in appearance to that shown in Fig. 9, and energy-dispersive $\mathrm{x}$-ray analysis of the microconstituents gave similar results.

Major oil impurities, which were not major elements in the original brick, include $\mathrm{Na}, \mathrm{Ni}, \mathrm{P}, \mathrm{S}$, and $\mathrm{V}$. We searched for these elements in the hot-face microconstituents, but none were found.

The microstructure of the small brick in a region of the hot face, shown in Fig. 13, is similar in appearance to that of the cold face. An energy-dispersive X-ray analysis of the grains (EDX V) shown in Fig. 14 reveals magnesium as the major element, with smaller amounts of $\mathrm{Cr}, \mathrm{Mn}$, and $\mathrm{Fe}$. The principal phases are probably periclase and magnesioferrite. Several dense regions, as shown in Fig. 15, were observed on the hot face. The dense regions in this specimen, however, do not resemble those in the large brick. Whereas those in the large brick consisted of rounded particles in a matrix, the region shown in Fig. 15 consists of angular light-gray particles distributed in a matrix. An energy-dispersive $\mathrm{x}$-ray analysis of the light area (EDX VI) shown in Fig. 16 reveals high concentrations of $\mathrm{Mg}, \mathrm{Al}, \mathrm{Si}, \mathrm{Cr}$, and $\mathrm{Fe}$ and barely detectable amounts of $\mathrm{K}$ and $\mathrm{Ca}$. These elements could be present in several of the phases listed in Table 4, but we cannot be certain of the composition. The characteristic $\mathrm{x}$-ray spectra for the matrix phase in the dense region (EDX VII) in Fig. 17 shows high concentrations of $\mathrm{Mg}, \mathrm{Al}$, and $\mathrm{Si}$, with smaller amounts of $\mathrm{K}, \mathrm{Ca}, \mathrm{Cr}$, and $\mathrm{Fe}$.

As in the case of the large brick, we searched for the major oil impurities, including $\mathrm{Na}, \mathrm{Ni}, \mathrm{P}, \mathrm{S}$, and $\mathrm{V}$, but none were found in detectable amounts.

Since no evidence for the presence of fuel impurities was shown by examination of polished sections of the refractories, fracture sections of both specimens were examined using scanning electron microscopy. The surface of a fracture section through the hot face of the small-brick specimen is shown 


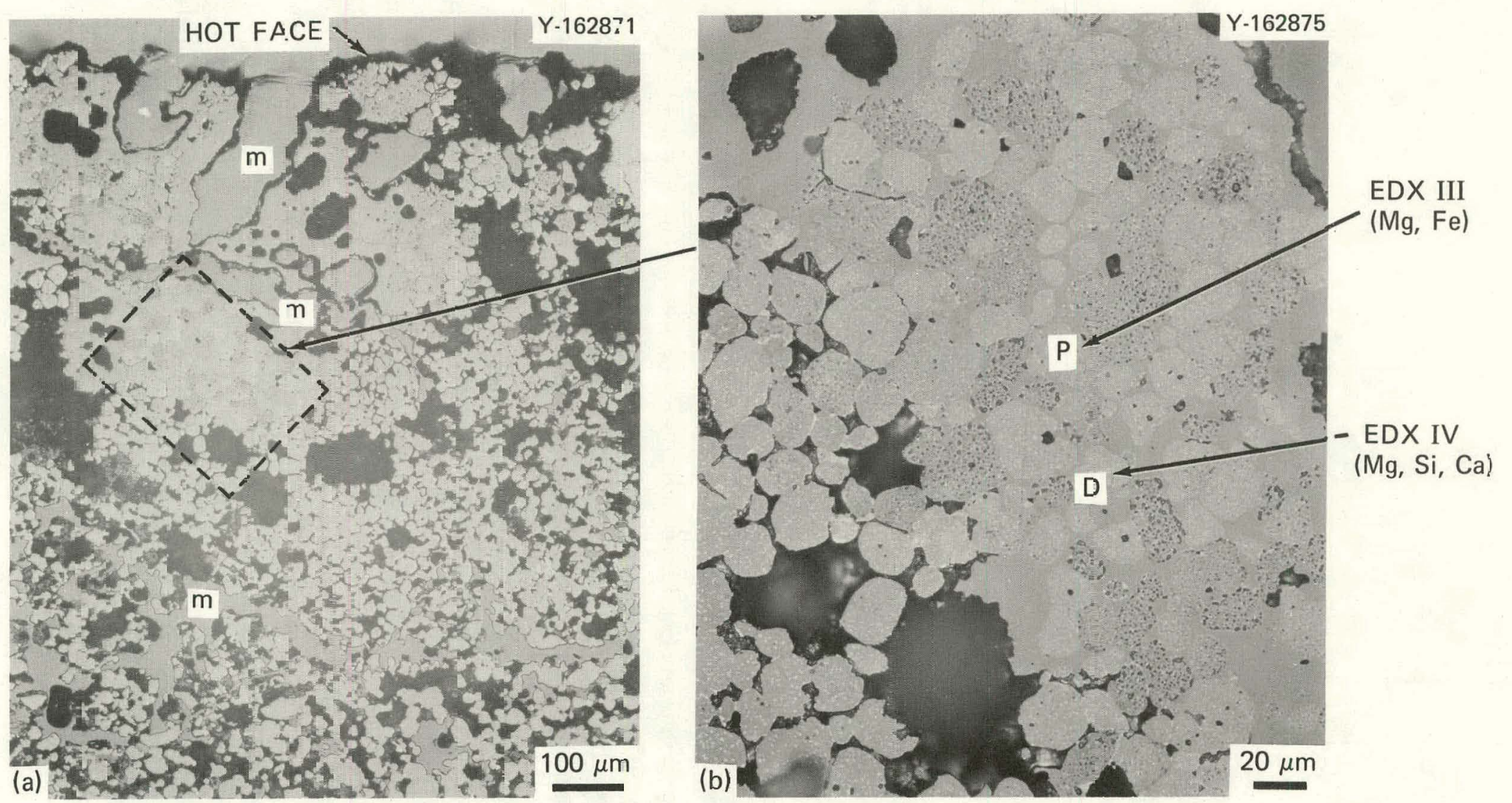

Fig. 5. Section through the hot face of large brick (sample 6B), (a) Showing region of densely packed grains, $100 \times$. (b) Showing mottled grains within the dense region, $400 \times . P$ : periclase $\mathrm{MgO} ; D$ : diopside, $\mathrm{CaO} \cdot \mathrm{MgO}^{\circ} \cdot 2 \mathrm{SiO}_{2}$. 


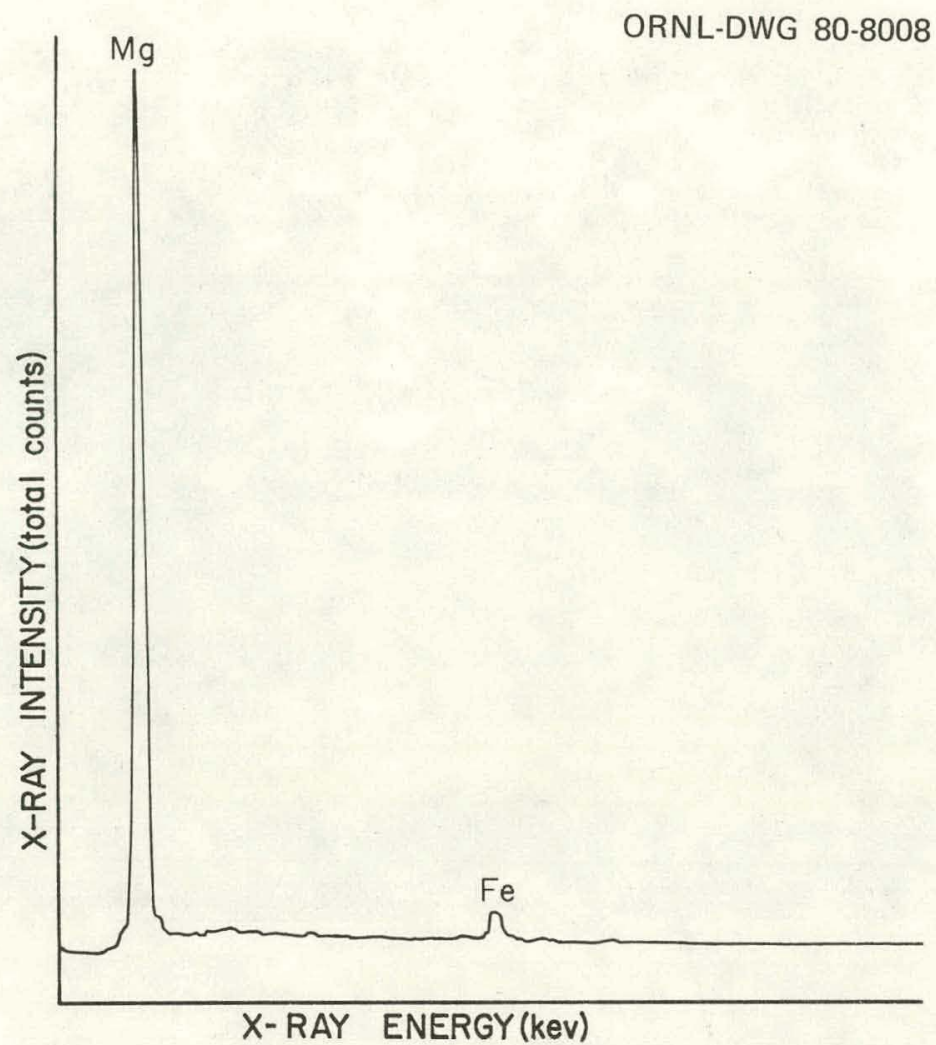

Fig. 10. Energy-dispersive $\mathrm{x}$-ray analysis plot for large brick: light-gray grains in the region of dense grains in Fig. 9 (EDX III).

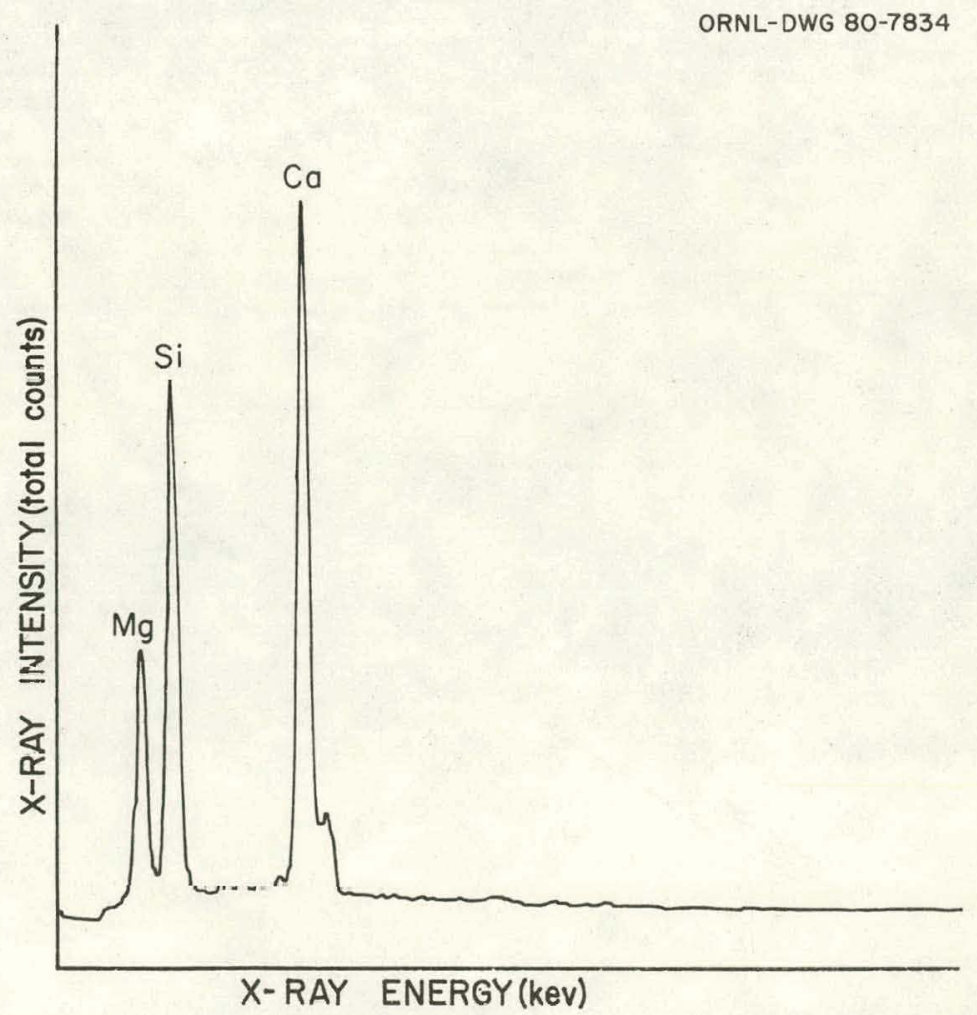

Fig. 11. Energy-dispersive $\mathrm{x}$-ray analysis plot of large brick: medium-gray grains in the region of dense grains in Fig. 9 (EDX-IV). 


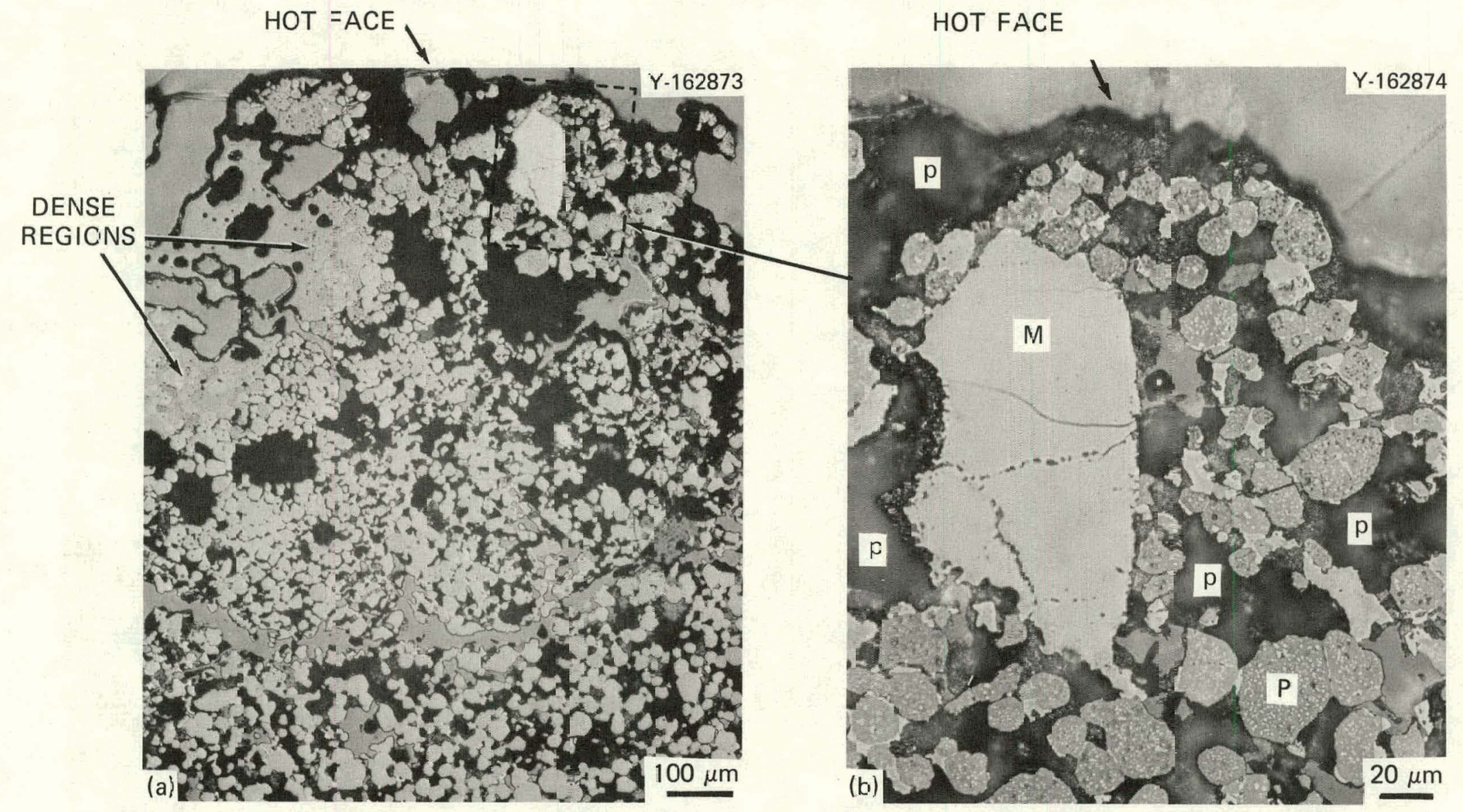

Fig. 12. Microstructure of hot face of large brick (sample 6B). (a) Showing typical area of toth loosely joned grains and dense regions, $100 \times$. (b) Showing mottled grains around a large particle, $400 \times . M$ : magnesiochromite, $(\mathrm{Mg}, \mathrm{Fe})(\mathrm{Cr}, \mathrm{Al})_{2} \mathrm{O}_{4} ; P$ : periclese, $\mathrm{MgO} ; p$ : porosity. 
HOT FACE

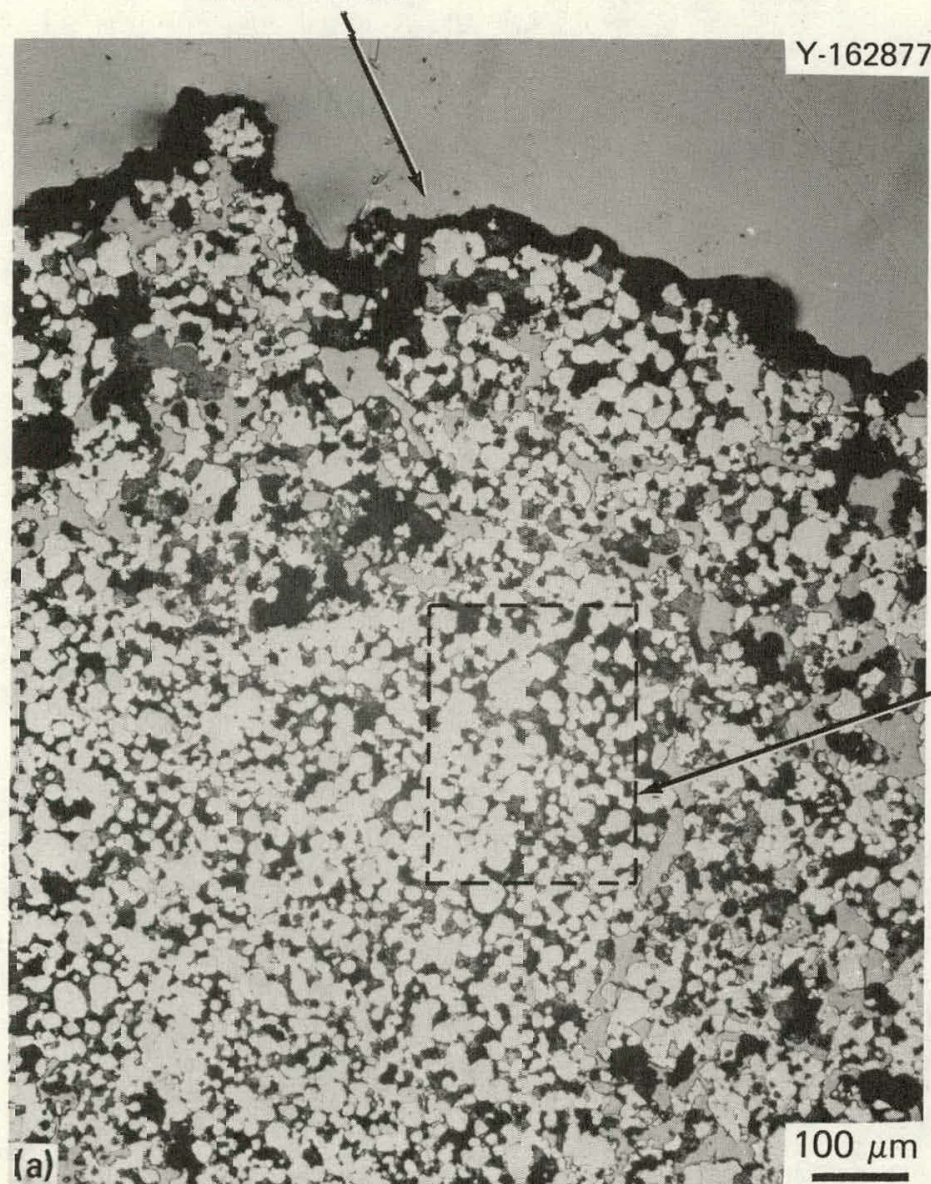

EDX V

$(\mathrm{Mg}, \mathrm{Cr}, \mathrm{Mn}, \mathrm{Fe})$

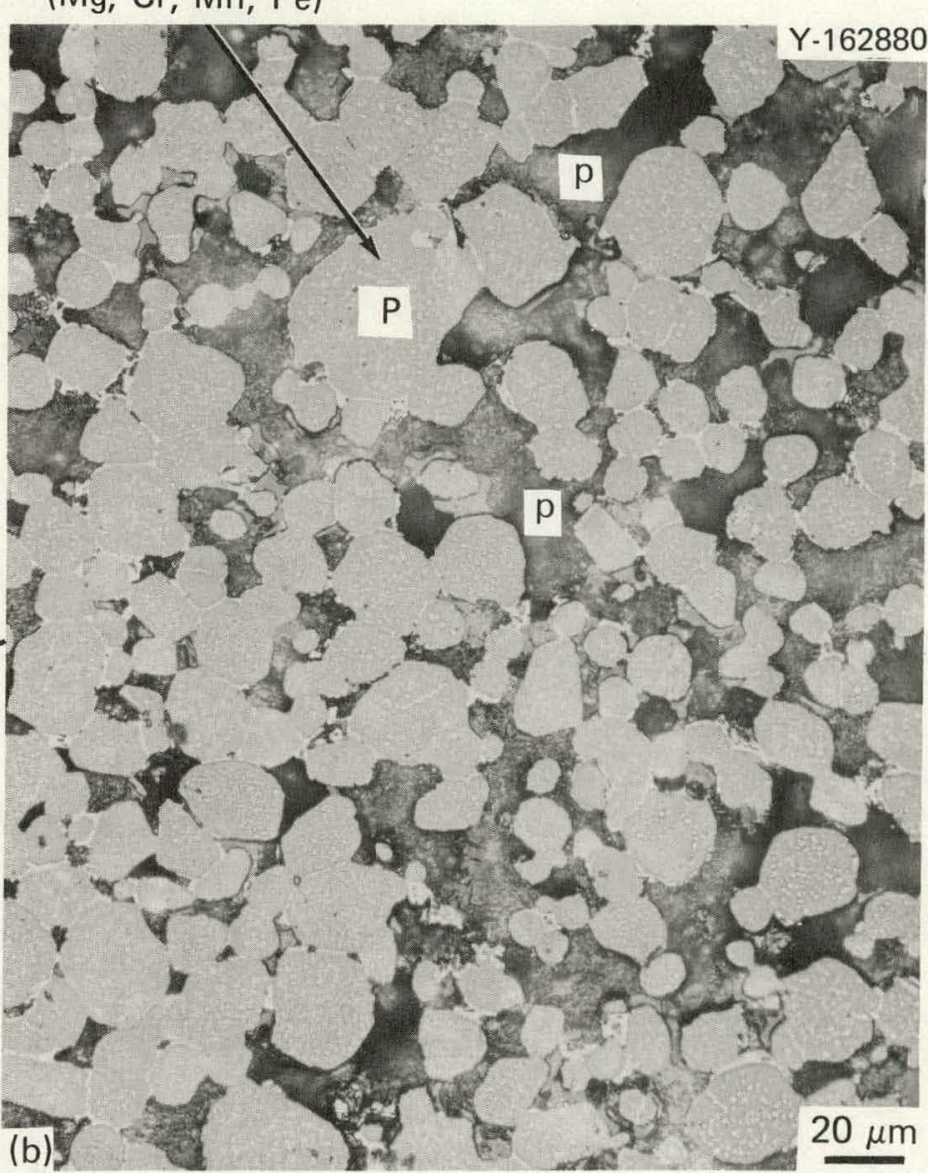

Fig. 13. Microstructure of hot face of small brick (sample 4B). (a) Showing an aggregate of small grains, 100x. (b) Showing loosely joined grains, $400 \times$. $P$ : periclasє, MgO; p: porosity. 


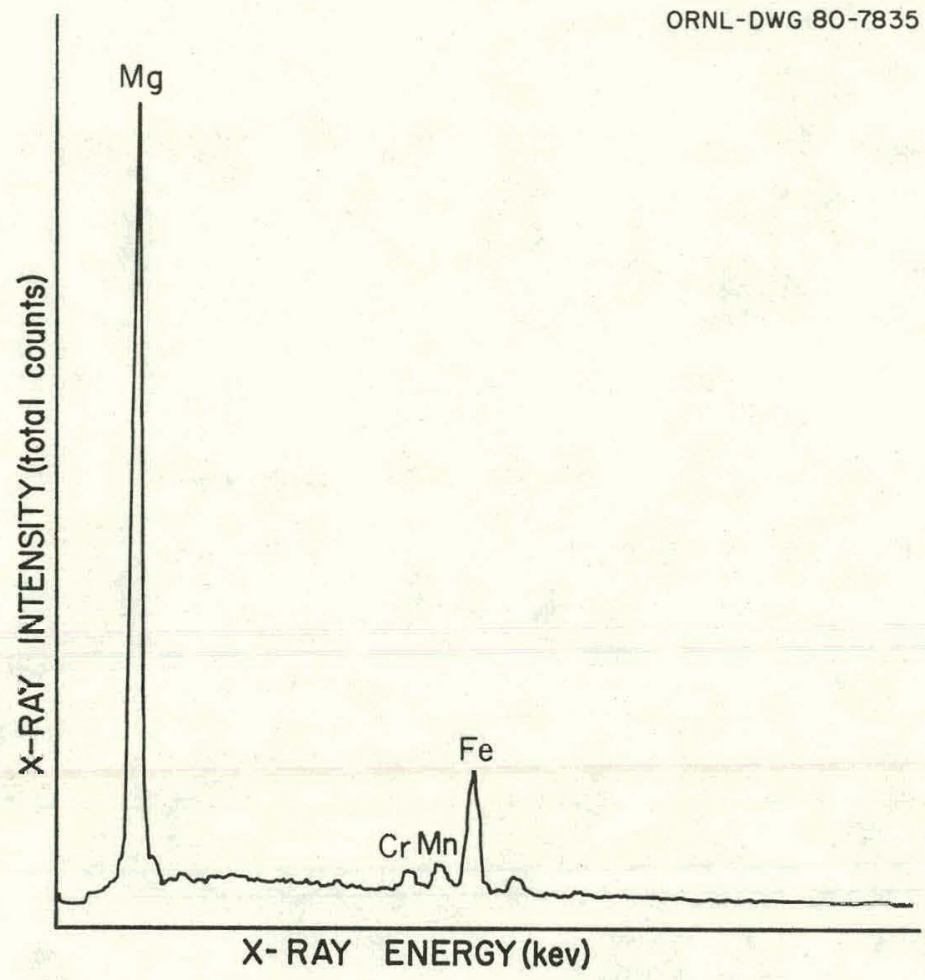

Fig. 14. Energy dispersive $x$-ray analysis plot for the small brick: grains in Fig. 13 (EDX V).

in Fig. 18. The previously mentioned green layer is visible as a thin dense region. An energy-dispersive $\mathrm{x}$-ray analysis of the green layer (EDX VIII) in Fig. 19 detected high concentrations of potassium and calcium. Magnesium, silicon, and chromium were also present, but aluminum and iron were absent. Several other regions near the hot face contained high concentrations of $\mathrm{Ca}, \mathrm{K}$, and $\mathrm{Mg}$. We found no fuel impurities which were not already major elements in the original brick. (Gold was coated on the specimen for analysis purposes and was neither an impurity in the brick or in the fuel oil.)

Figure 20 shows a fracture section through the hot face of the large-brick specimen. An energydispersive $\mathrm{x}$-ray analysis of the reaction layer in Fig. 21 detected $\mathrm{Si}, \mathrm{K}, \mathrm{Cr}$, and $\mathrm{Fe}$. Other regions had high concentrations of $\mathrm{Mg}, \mathrm{Al}, \mathrm{Si}, \mathrm{K}, \mathrm{Ca}, \mathrm{Cr}$, and $\mathrm{Fe}$, but no fuel impurities such as $\mathrm{Na}, \mathrm{Ni}, \mathrm{P}, \mathrm{S}$, and $\mathrm{V}$. We conclude that neither the reaction layer nor the near-surface region contains impurities directly traceable to the fuel oil. The high concentrations of nntassium frequently observed were probably derived from the materials being heated in the kiln. 


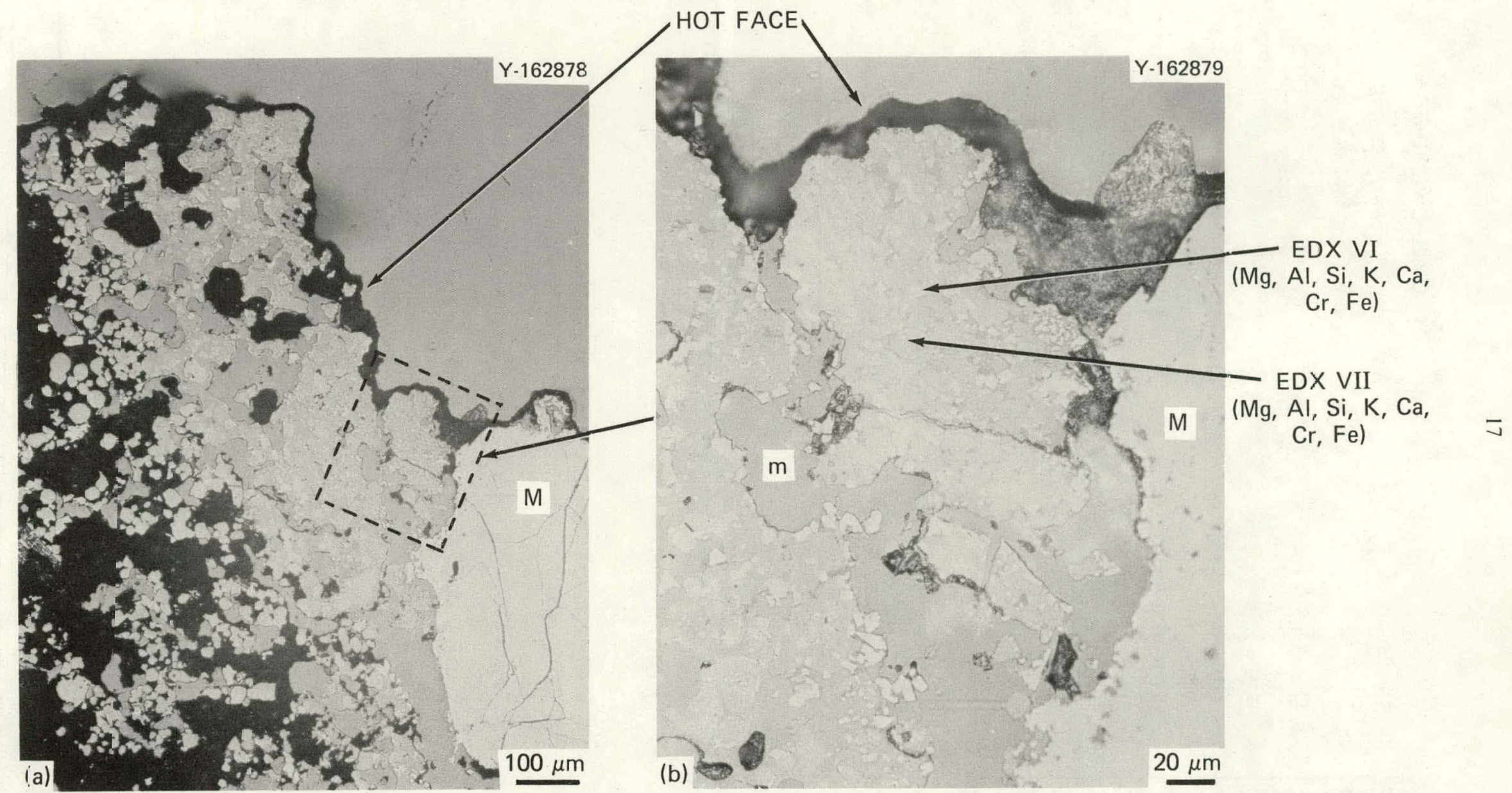

Fig. 15. Microstructure of hot face of small brick (sample 4B). (a) Showing region of dense grains at the surface, 100X. (b) Showing the dense region at 400X. M: maznesiochromite, $(\mathrm{Mg}, \mathrm{Fe})(\mathrm{Cr}, \mathrm{Al})_{2} \mathrm{O}_{4} ; m$ : mounting material. 


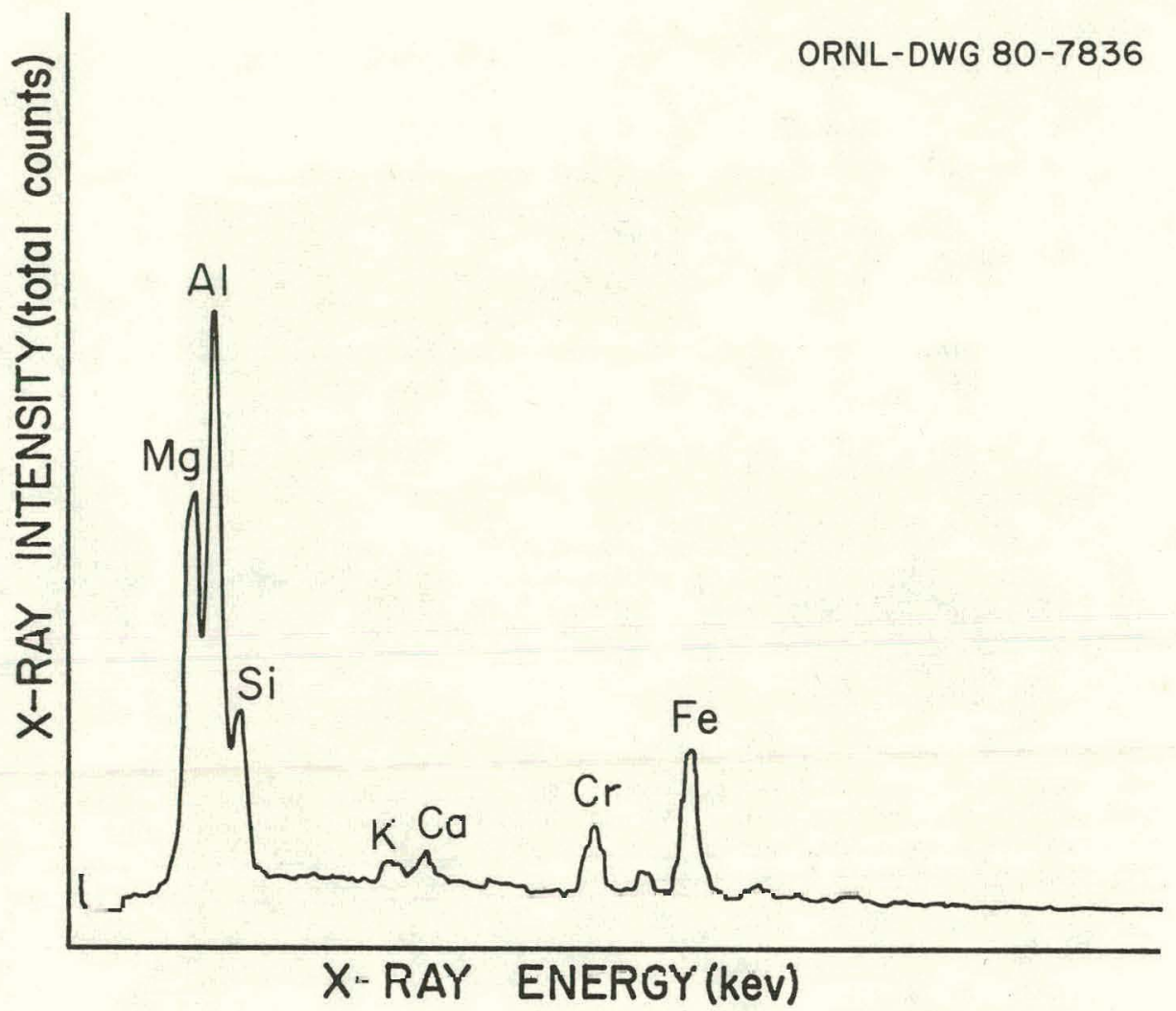

Fig. 16. Energy-dispersive $\mathrm{x}$-ray analysis plot for small brick: light-gray area in dense region of Fig. 15 (EDX VI).

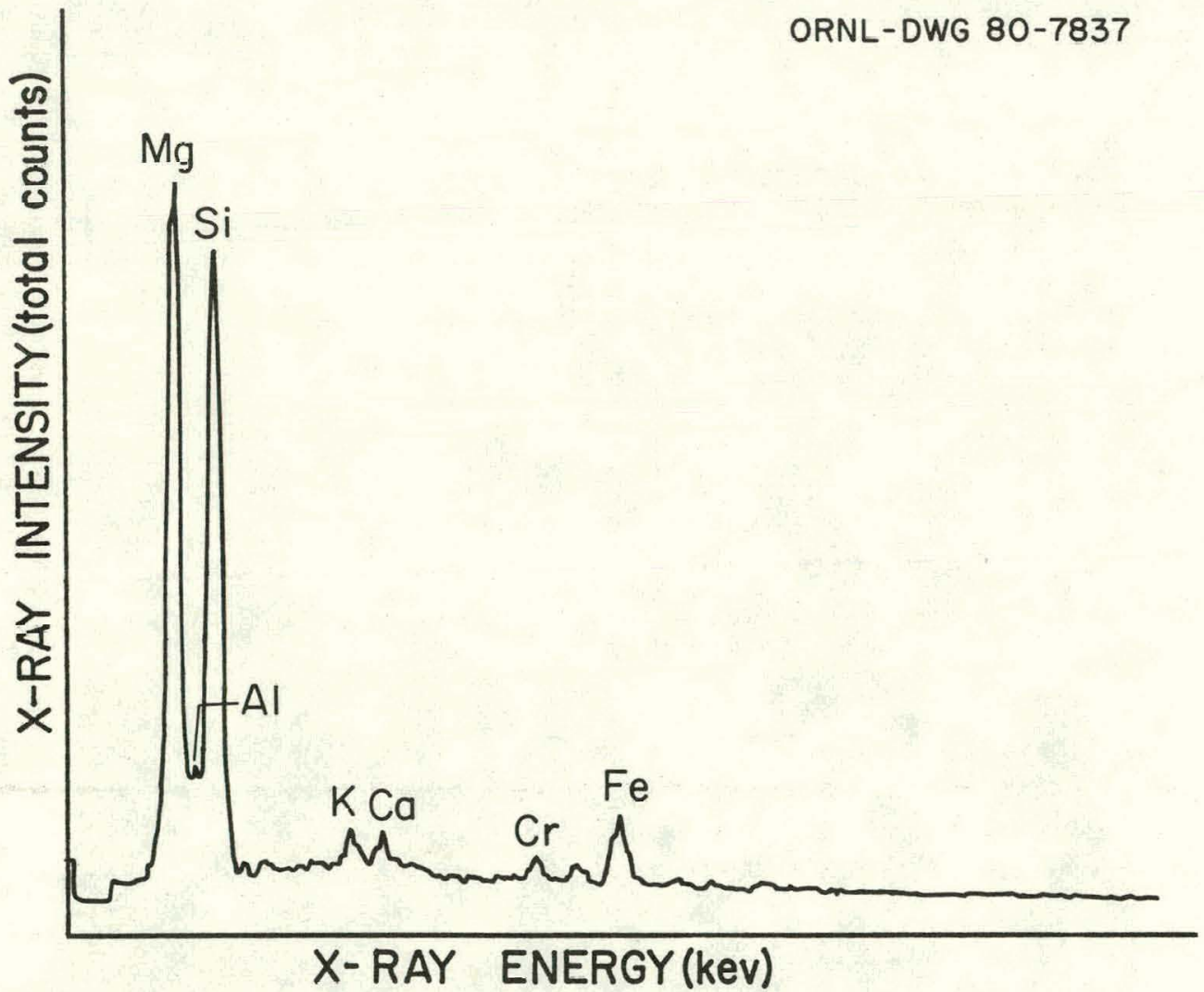

Fig. 17. Energy-dispersive $\mathrm{x}$-ray analysis plot for small brick: medium-gray area in dense region of Fig. 15 (EDX VII). 


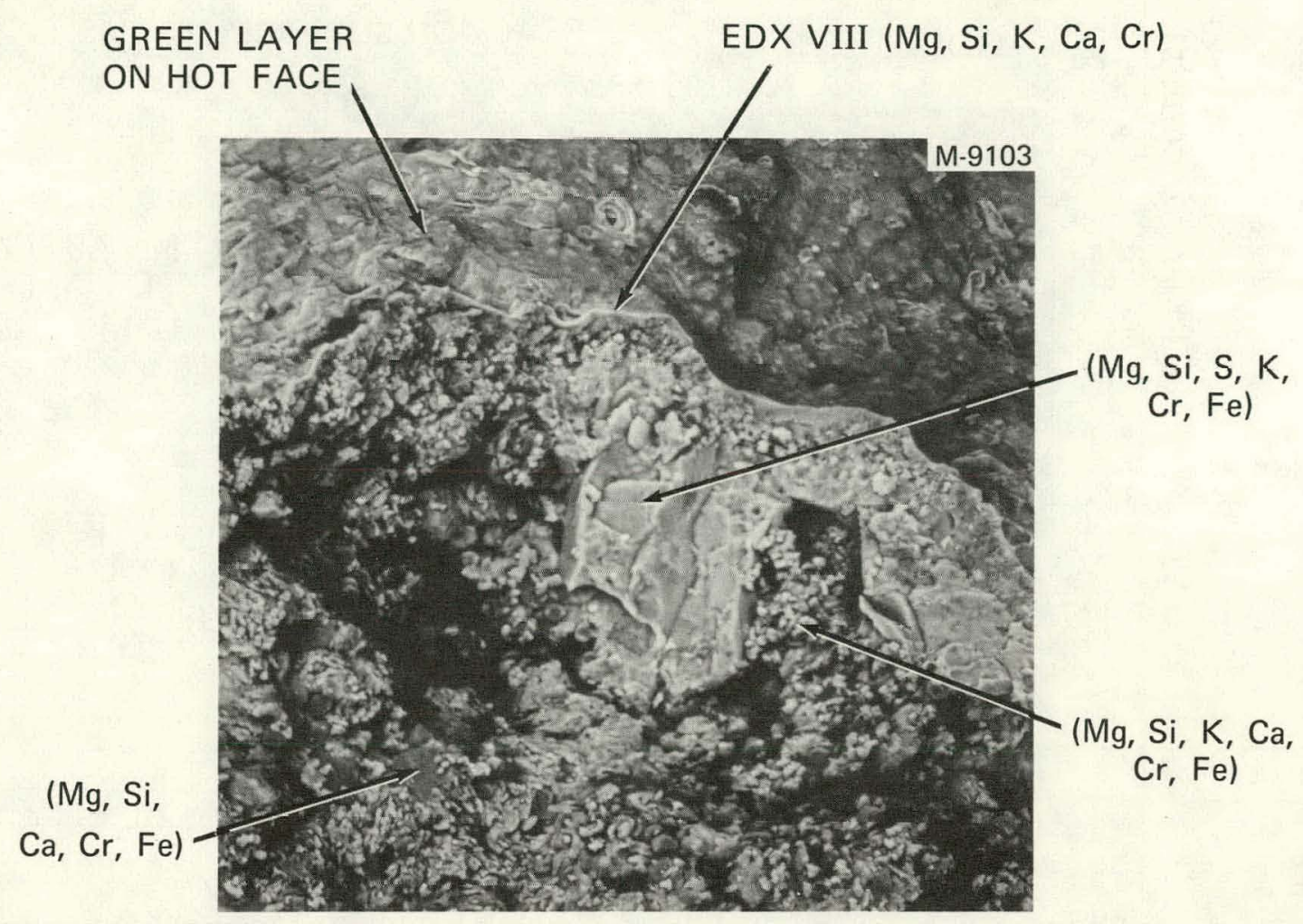

Fig. 18. Scanning electron microscope picture of fracture section through hot face of small brick.

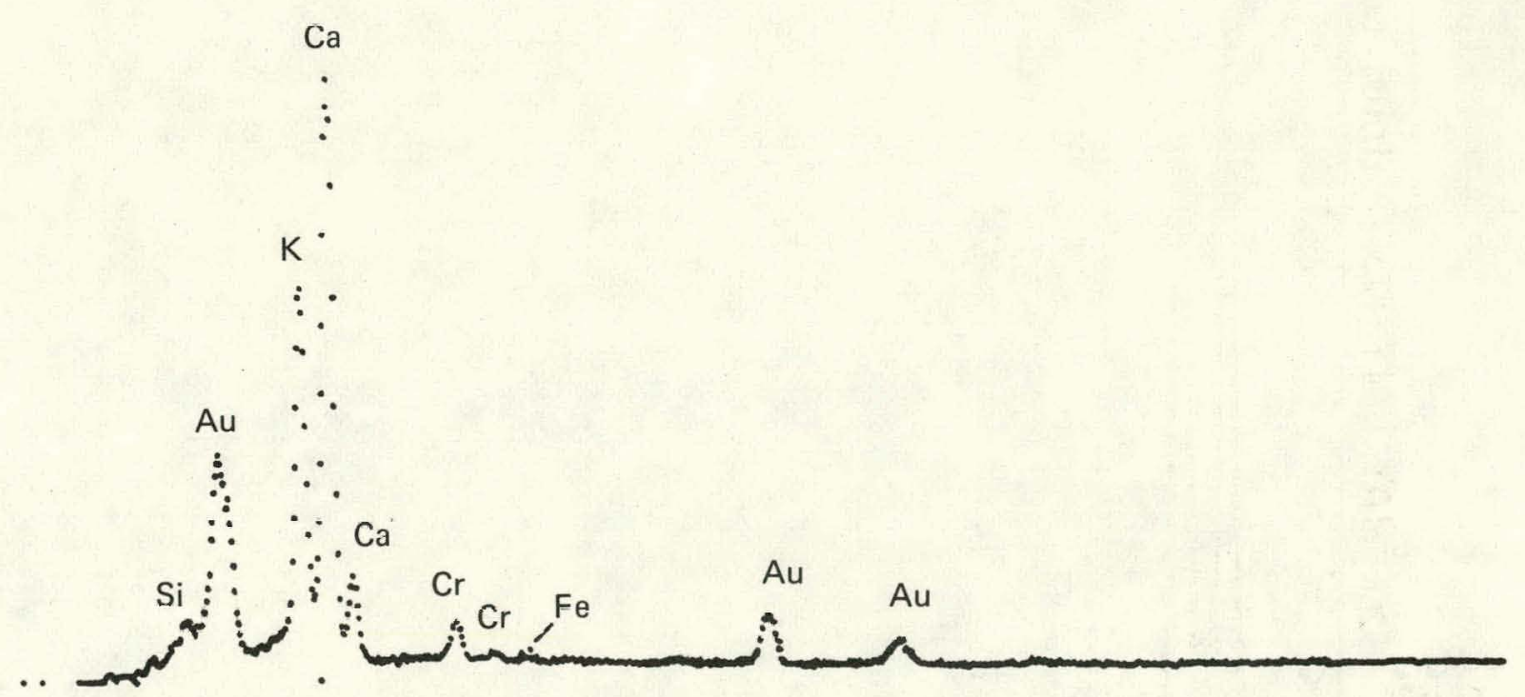

Fig. 19. Energy-dispersive $\mathrm{x}$-ray analysis plot for small brick: green layer on hot face (EDX VIII). Gold was applied during specimen preparation. 


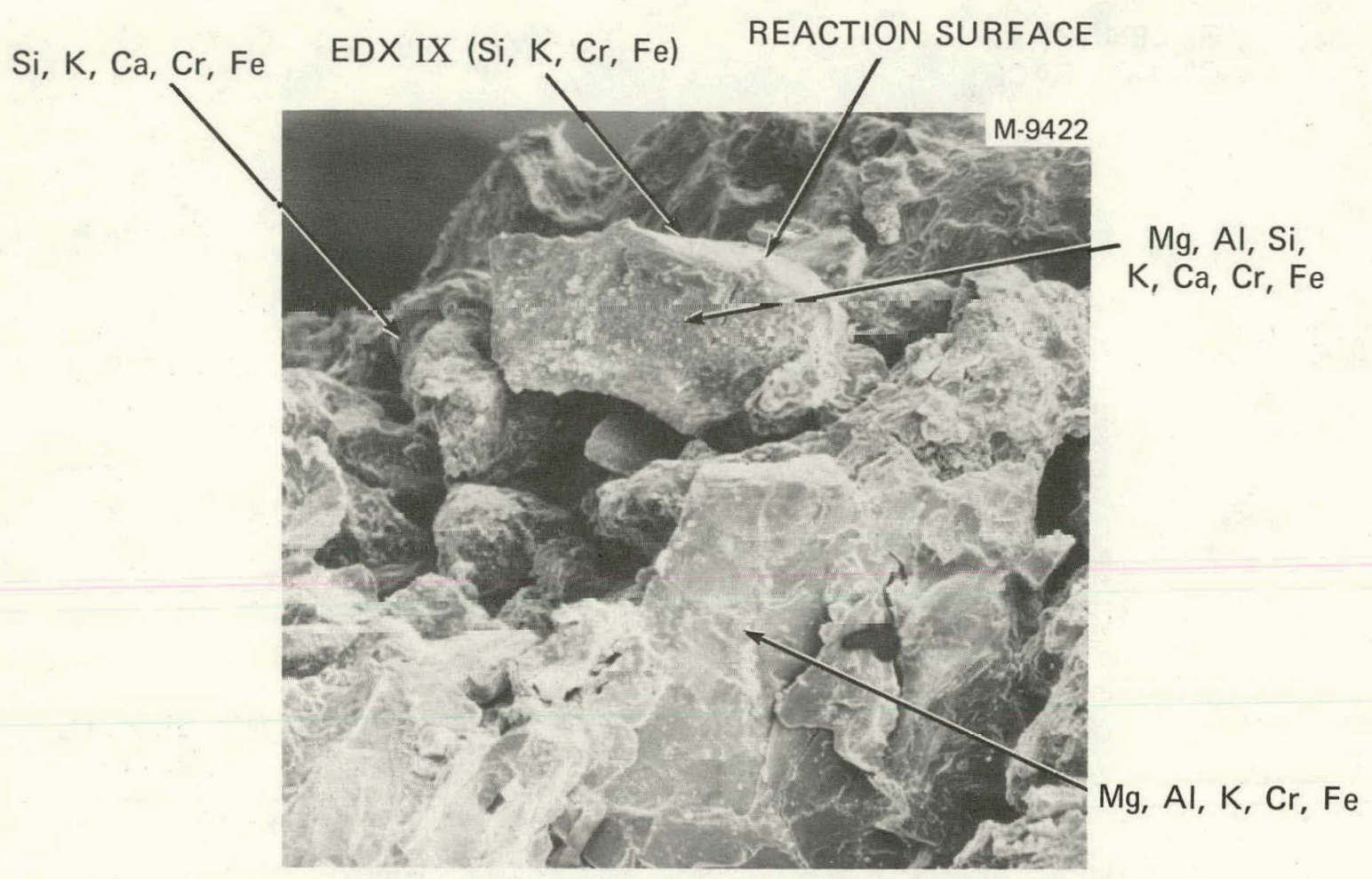

Fig. 20. Scanning electron microscope picture of fracture section through hot face of large brick.

ORNL-DWG 80-7839

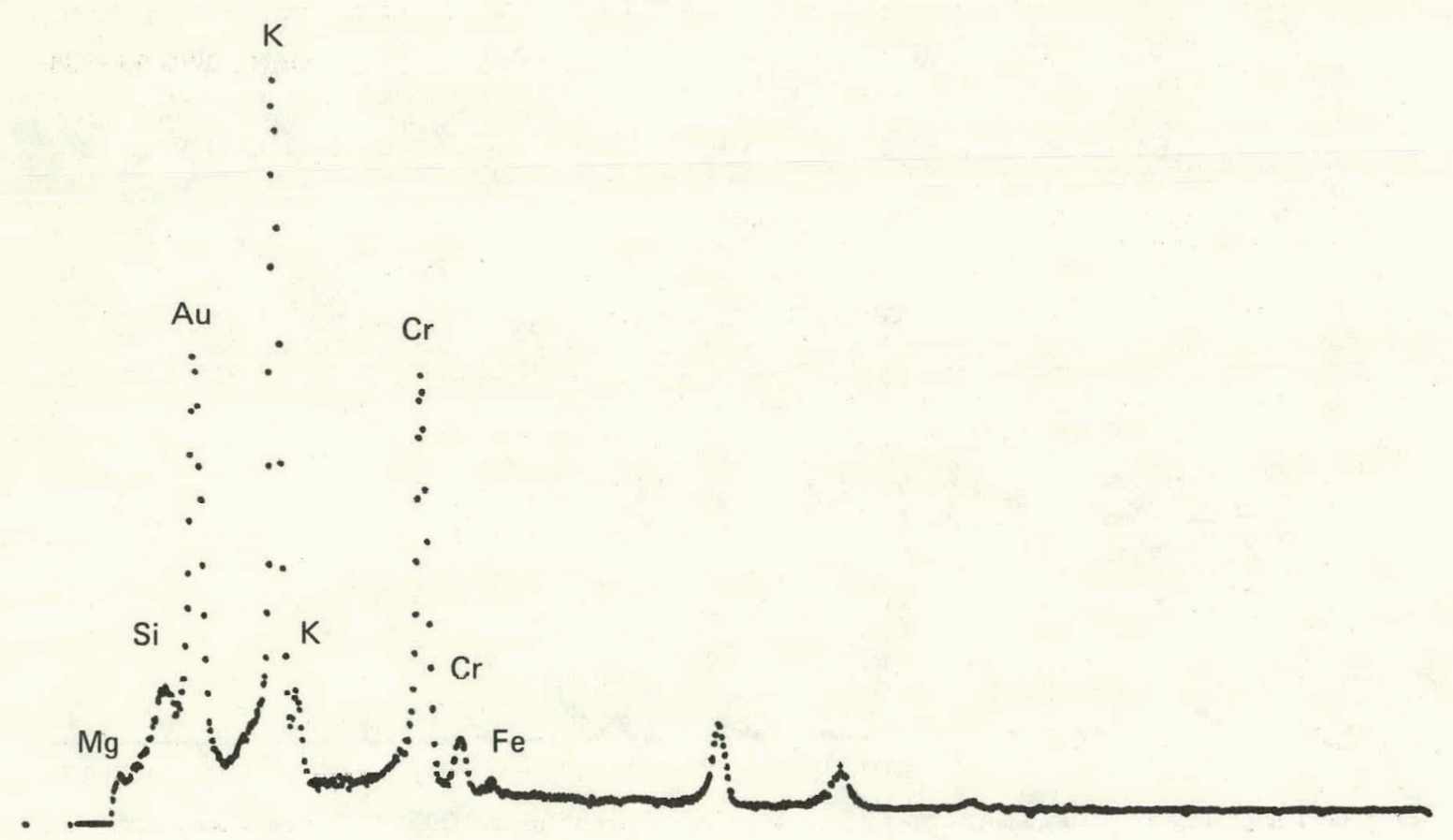

Fig. 21. Energy-dispersive x-ray analysis plot for large brick: reaction surface in Fig. 20. Gold was applied during specimen preparation. 


\section{DISCUSSION}

The two magnesia-based brick specimens have been analyzed to determine whether the observed degradation was caused by fuel impurities. The principal fuel impurities were $\mathrm{Ca}, \mathrm{Fe}, \mathrm{Mg}, \mathrm{Na}, \mathrm{Ni}, \mathrm{P} . \mathrm{S}$, and $\mathrm{V}$. Since $\mathrm{Ca}, \mathrm{Fe}$, and $\mathrm{Mg}$ were also principal elements in the original bricks, an increase in the concentration of these elements from the combustion products of the fuel would probably not be harmful to the bricks. On the other hand, degradation processes involving $\mathrm{Na}, \mathrm{Ni} ; \mathrm{P}, \mathrm{S}$, and $\mathrm{V}$ would probably be identifiable. However, neither chemical analyses of the hot-face regions nor electron microprobe analyses of both polished and fractured sections of the hot-face regions revealed significant concentrations of these elements. As a result, there is no evidence to show that $\mathrm{Na}, \mathrm{Ni}, \mathrm{P}$, and $\mathrm{V}$ impurities contributed to degradation of these bricks.

The low concentrations of most fuel impurities in the hot-face region of the bricks are probably related to the operating conditions in the kiln. During normal operation, material constantly passed through the kiln, beginning at the cold end of the kiln as a blend of powder ingredients and exiting at the hot end as newly formed compounds in the form of clinker. At any stage of reaction the kiln contents have a relatively high surface area compared with the brick lining in the kiln. The kiln product contained approximately $65 \% \mathrm{CaO}, 25 \% \mathrm{SiO}_{2}, 5 \% \mathrm{Al}_{2} \mathrm{O}_{3}$, and $5 \% \mathrm{Fe}_{2} \mathrm{O}_{3}$ (equivalent oxide content). Fuel impurities in the combustion products probably reacted to form stable compounds with the material passing through the kiln and also with that part of the material which formed a coating on the kiln wall. Vanadium pentoxide, for example, forms at least three compounds with $\mathrm{CaO}$, including $\mathrm{CaO} \cdot \mathrm{V}_{2} \mathrm{O}_{5}$. $2 \mathrm{CaO} \cdot \mathrm{V}_{2} \mathrm{O}_{s}$, and $3 \mathrm{CaO} \cdot \mathrm{V}_{2} \mathrm{O}_{s} .{ }^{11}$. The high $\mathrm{CaO}$ concentration in the kiln contents might also promote a reaction with $\mathrm{SO}_{2}$ to form $\mathrm{CaSO}_{+}$, thereby chemically neutralizing much of the sulfur in the combustion products.

Since the product was constantly moving through the kiln, and since the coating on the bricks spalled periodically, the fuel impurities had limited opportunity to penetrate deeply and react with the bricks. The fuel impurities most probably left the kiln as constituents of the cement clinker. The kiln operators stated that the rate of degradation of the bricks was similar to that experienced with natural gas as a fuel instead of residual oil; therefore the degradation in this case appears to be normal for the severe conditions in the burning zone of the kiln and was not significantly influenced by reactions with fuel impurities.

\section{CONCLUSIONS}

Two degraded magnesia-based bricks from the burning zone of a residual oil-fired rotary cement kiln have been analyzed to determine whether fuel oil impurities caused a significant part of the observed degradation. These refractories were exposed to the kiln contents and to fuel oil impurities at a temperature of $\sim 1500^{\circ} \mathrm{C}$ for six to nine months. The results of chemical analyses, $x$-ray diffraction, ceramography, and electron microprobe analyses allow the following conclusions:

1. The hot-face regions of the bricks did not contain high concentrations of fuel impurilies relative to the cold-face regions.

2. No new crystalline phases were identified in the hot-face regions of the bricks.

3. Except for isolated regions of denser material on the hot face, the microstructure of the hot-face regions was similar to that of the cold-face regions.

4. Fuel impurities were not identified in either polished or fracture sections through the ref ractory hot face, using electron microprobe analysis.

5. Degradation of the refractories appears to be normal and unrelated to specific fuel impurities. 


\section{ACKNOWLEDGMENTS}

The authors wish to acknowledge the contributions of others to the completion of this work: J. W. Geer, sample preparation; W. H. Warwick, ceramography; R. S. Crouse, electron microprobe analysis; T. J. Henson, scanning electron microscopy; and O. B. Cavin, $x$-ray diffraction analysis. We thank J. R. Keiser and C. S. Morgan for their critical review and comments.

\section{REFERENCES}

1. G. C. Wei, L. A. Harris, and V. J. Tennery, Effects of Alternate Fuels, Report No. I. Analysis of High-Duty Fireclay Refractories Exposed to Coal Combustion, ORNL/TM-5909 (December 1977):

2. G. C. Wei and V. J. Tennery, Effects of Alternate Fuels, Riporl No. 2, Analysis of Busic Refracturies Degraded hy Residual Oil Combustion Products, ORNI./TM-finRs (Frbruary 1978).

3. G. C. Wei and V. J. Tennery, Effecis of Alternate Fuels. Report No. 3, Analysis of High Duty. Fireclay Refractories Degraded by Residual Oil Combustion Products.' ORNL/TM-6184 (April 1978).

4. G. C. Wei and V. J. Tennery, Effects of Alternate Fuels, Report No. 4, Analisis of Suaking Ph Cover Refractories Degraded by Residual Oil Combustion Products, ORNL/TM-6204 (April 1978).

5. G. C. Wei and V. J. Tennery, Effects of Alternate Fuels, Report No. 5, Analysis of Fused Cast AZS Refractory, Silica Refractory, and High-MgO Refractory Degraded by Residual Oil Combustion Products, ORNL/TM-6278 (April 1978).

6. G. C. Wei and V. J. Tennery, Effects of Alternate Fuels, Report No. 6, Analysis of Low' Alumina Castable Refractory Degraded by Residual Oil Combustion Products, OR NL/TM-6334 (July 1978).

7. J. I. Federer and V. J. Tennery, Effects of Alternate Fuels. Report No. 7, Analysis of Failure of a Mullite-Based Refractory Brick in an Industrial Bil-Fired, Rurner, OR.NL./TM-6878 (July 1979).

8. A. E. Pasto and V. J. Tennery, Effects of Alternate Fuels, Refractory Test Facility (RTF) Test I, Analysis of Selected Aluminosilicate Refractory Bricks, Mortars, and Filıuus Irsulatlons. Degraded by Domestic Residual Oil Combustion Products, ORNL/TM-635I (June 1978).

9. J. I. Federer and V. J. Tennery, Effects of Alternate Fuels, Refractory Test Facility (RTF) Test 2 , Evaluation of Magnesia-Based Bricks and Mortar und Alumina-Based Bricks, Castables, and Fibrous Insulations Exposed to Residual Oil Combustion Products, ORNL/TM-6840 (March 1980).

10. A. N. Mornzov, Metallurg (Leningrad) 13(12), 21-28 (1938). 
INTERNAL DISTRIBUTION

1-2. Central Research Library

3. Document Reference Section

4-5. Laboratory Records Department

6. Laboratory Records, ORNL R.C.

7. ORNL Patent Section

8. R. L. Beatty

9. R. A. Bradley

10. G. W. Brassell

11. R. S. Carlsmith

12. J. V. Cathcart

13. R. G. Donnelly

14-23. J. I. Federer

24. G. R. Gessel

25. T. G. Godfrey

26. R. J. Gray
27. M. R. Hill

28. H.W. Hoffman

29. J.R. Keiser

30. L. E. McNeese

31. A. E. Pasto

32. A. C. Schaffhauser

33. J. E. Selle

34-43. V. J. Tennery

44. T. N. Tiegs

45. G. C. Wei

46. A. L. Bement, Jr. (Consultant)

47. W. R. Hibbard, Jr. (Consultant)

48. M. J. Mayfield (Consultant)

49. J. T. Stringer (Consultant)

EXTERNAL DISTRIBUTION

50. R. W. Anderson, Diversified Insulationi, Inc., P.O. Box 188, Hamel, MI 55340

51. N. Ault, Norton Company, One New Bond Street, Worcester, MA 01606

52. J. E. Bailey, Raw Materials Specialist, Ford Motor Company, Glass Technical Center, 25500 West Outer Drive, Lincoln Park, MI 48146

53. W. T. Bakker, Electric Power Research Institute, 3412 Hillview Avenue, Palo Alto, CA 94304

54. L. Baumer, Ownes-Illinois, Inc., P.O. Box 1035, Toledo, OH 43666

55. D. R. Bissel, Drexel Refractories Co., Box 50, Kittaning, PA 16201

56. I. W. Bjerklie, Hague International, 3 Adams Street, South Portland, MA 04106

57. D. S. Blum, Quality Control Manager, Plibrico Company, 1800 N. Kingsbury Street, Chicago, IL 60614

58. G. E. Brinkerhoff, Manager, Technical Services, A. P. Green Refractories Company, Mexico, MO 65265

59. J. J. Brown, Dept. of Materials Engineering, Virginia Polytechnic Institute and State University, Blacksburg, VA 24061

60. J. D. Dorn, Southwestern Portland Cement Company, P.O. Box 937, Victorville, CA92305

61. J. Eustis, Division of Industrial Energy Conservation, Department of Energy, 20 Massachusetts Ave., NW, Washington, DC 20545

62. W. X. Fay, General Refrastories Co., 50 Monument Rd., Bala-Cynwyd, PA 19004

63. M. P. Fedock, Assistant Division Head, Iron and Steelmaking Division, Republic Steel Corporation, Research Center, 6801 Brecksville Road, Cleveland, OH 44131

64. Robert A. Fenimore, ICI Americas, Inc. Specialty Chemicals Division, Wilmington, DE 19849

65. L. E. Ferreira, Interpace Corporation, Corporate Headquarters, Box 1111, Parsippany, NJ 07054 
66. R. E. Ferris, Kaiser Research Center, Box 870, Pleasanton, CA 94566

67. R. Grekrila, Research Center, Westinghouse Electric Corp., Beulah Road, Pittsburgh, PA 15235

68. R. S. Harris, Anchor Hocking Company, Lancaster, OH 43135

69. D. Harvey, Department of Energy, 20 Massachusetts Ave., NW, Washington, DC 20545

70. R. H. Herron, Homer Research Laboratory, Bethlehem Steel Corporation, Bethlehem, PA 18017

71. H. L. Johns, Zircoa Products, 31501 Solon Road, Solon, OH 44139

72. K. K. Kappmeyer, Applied Research Laboratory, United States Steel Corp., Monroeville, PA 15146

73. C. R. Kennedy, Argonne National Laboratory, 9700 N. Cass Avenue, Argonne, IL 60439

74. W. D. Kingery, Department of Materials Science and Engineering, Massachusetts Institute of Technology, Cambridge, MA 02139

75. L. Krietz, Plibrico Company, 1800 N. Kingsbury Street, Chicago, IL 60614

76. L. J. Kuhlman, Monsanto Company, 800 N. Lindberg Blvd., St. Louis, MO 63166

77. R. G. LaBar, Alcoa Research Laboratories, Aluminum Company of Americu, Alcon Center, PA 15069

78. R. A. Landy, Director of Research, North American Refractories Company Research Center, Curwensville, PA 16833

79. J. Langensiepen, Brockway Glass Company, Central Laboratory, Brockway, PA 15824

80. C. Lindsay, Tennessee Valley Authority, 303 Union Bldg., Knoxville, TN 37902

81. J. R. McGaughey, Bickley Furnaces, Inc., 550 State Road, Philadelphia, PA 19114

82. T. D. McGee, Iowa State University, Materials Science and Engineering Department, Ames, IA 50010

83. R. W, Marshell, North American Manufacturing Company, 4455 E. 71 st Street, Cleveland, OH 44105

84. W. Mead, Temtek-Allied Division, Ferrn Corp., One Erievicw Place, Cleveland, OH 44114

85. R. J. Moffat, Pullman-Swindell, 441 Smithfield Street, Pittsburgh, PA 15222

86. R. Neeley, Chattanooga Glass Company, 400 W. 45 th Street, Chattanooga, TN 37410

87. J: A. Nelson, University of Illinois, Urbana, IL 61801

88. R. E. Nelson, C-E Minerals Company, 901 E. 8th Avenue, King of Prussia, PA 19406

89. T. H. Nielsen, Coors Porcelain 'Company, 6009 th Street, Golden, CO 80401

90. D. Olenchut, Jones and Laughlin Steel Corp., 3A, Gateway Center, Pittsburgh, PA 15230

91. J. Osborne, Division of Industrial Energy Conservation, Department of Energy, 20 Massachusetts, Ave., NW, Washington, DC 20545

92. P. Papa, Corhart Refractories Co., 1600 W. Lee Street, Louisville, KY 40210

93. J. D. Parsons; Chicago-Wellsville Fire Brick Company, 1467 Elston Ave., Chicago, IL 60622

94. C. M. Pelanne, Johns-Manville Corp., Box 5108, Denver, CO 80217

95. M. Perlsweig, Fuel Utilization Division, Fossil Enlergy, E 178, Department of Energy, Washington, DC 20543

96. G. V. Prible, C-E Refractories Co., (Div. of Combustion Engineering, Inc.), Box 828, Valley Forge, PA 19482

97. R. Ramey, Inland Steel Research, 3001 Ėast Columbus Drive, East Chicago, IN 46312

98. R. Rose, H. K. Porter Co., Porter Bldg., 601 Grant St., Pittsburgh, PA 15219 
99: R: P. Ross, Glasrock Products, Inc., 2210 Marietta Blvd., NW, Atlanta, GA 30318

100. G. R. Rowland, Hartford Refractories, Emhart Corp., P.O. Box 2809, Hartford, CT 06101

101. S. J. Schneider, U.S. Department of Commerce National Bureau of Standards, Materials Bldg. B-120, Washington, DC 20234

102. F. E. Schmidt, E. I. DuPont de Nemours \& Co., Inc., Experimental Stations, Bldg. 304, Wilmington, DE 14898

103. R. L. Sheneman, Acting Chief, High Temperature Processes Branch, Department of Energy, 20 Massachusetts, Avenue, Washington, DC 20585

104. R. L. Shultz, Armco Steel Corp., Research Center South, Middletown, OH 45043

105. R: R. Smyth, FluiDyne Engineering Co., 5900 Olson Memorial Highway, Minneapolis, MN 55422

106. L. H. Sweet, Manager Technical Development, Carborundum Co., P.O. Box 808, Niagara Falls, NY 14302

107. W. H. Thielbahr, Idaho Operations Office, Department of Energy, Idaho Falls, Idaho 83401

108. E. A. Thomas, Charles Taylor Div., NL Industries, Inc., 8361 Broadwell Road, P.O. Box 44040, Cincinnati, OH 45244

109. B. S. Tucker, The Refractories Inst., 1102 One Oliver Plaza, Pittsburgh, PA 15222

110. M. L. Van Dreser, Center for Technology, Kaiser Aluminum and Chemical Corp., Box 870, Pleasanton, CA 94566

111. J. Wosinsky, Corning Glass Works, Box 432, Corning, NY 14830

112. R. L. Yeckley, Industrial Market, Harbison-Walker Refractories, Division of Dresser Industries, Inc., 2 Gateway Center, Pittsburgh, PA 15222

113. C. E. Zimmer, Babcock and Wilcox Co., Lynchburg, VA 24505

114. Assistant Manager, Energy Research and Development, Department of Energy, Oak Ridge Operations Office, P.O. Box E, Oak Ridge, TN 37830

115-141. Department of Energy, Technical Information Center, Office of Information Services, P.O. Box 62, Oak Ridge, TN 37830 